Review

\title{
In Vitro Assembly of Virus-Like Particles and Their Applications
}

\author{
Dinh To Le and Kristian M. Müller*(D)
}

Cellular and Molecular Biotechnology, Faculty of Technology, Bielefeld University, 33615 Bielefeld, Germany; dinh_to.le@uni-bielefeld.de

* Correspondence: kristian@syntbio.net; Tel.: +49-521-106-6323

Citation: Le, D.T.; Müller, K.M. In Vitro Assembly of Virus-Like Particles and Their Applications. Life 2021, 11, 334. https://doi.org/ $10.3390 /$ life11040334

Academic Editors: Adam Taylor and Marko Noerenberg

Received: 23 December 2020

Accepted: 7 April 2021

Published: 10 April 2021

Publisher's Note: MDPI stays neutral with regard to jurisdictional claims in published maps and institutional affiliations.

Copyright: (c) 2021 by the authors. Licensee MDPI, Basel, Switzerland. This article is an open access article distributed under the terms and conditions of the Creative Commons Attribution (CC BY) license (https:// creativecommons.org/licenses/by/ $4.0 /)$.
Abstract: Virus-like particles (VLPs) are increasingly used for vaccine development and drug delivery. Assembly of VLPs from purified monomers in a chemically defined reaction is advantageous compared to in vivo assembly, because it avoids encapsidation of host-derived components and enables loading with added cargoes. This review provides an overview of ex cella VLP production methods focusing on capsid protein production, factors that impact the in vitro assembly, and approaches to characterize in vitro VLPs. The uses of in vitro produced VLPs as vaccines and for therapeutic delivery are also reported.

Keywords: capsid protein; in vitro assembly; virus-like particle; VLP-based vaccines; drug delivery

\section{Introduction}

Virus-like particles (VLPs) are highly structured protein complexes that resemble a native virus capsid. VLPs typically represent gene-less virus shells but in a wider definition encompass any type of capsid-derived nanoparticle. VLPs assemble from single or multiple structural capsid proteins inside appropriate production hosts, which is often termed in vivo assembly, as the host is seen as a single-cell organism, or in defined, cell-free conditions, also termed in vitro assembly. VLPs in general can be either enveloped or non-enveloped [1], whereby in vitro assembly typically leads to protein-only shells. Due to the lack of viral genomes, these particles are non-replicative but typically retain the transduction potential of the parental viruses, which may be used for nanoparticle delivery systems [2].

In vivo-produced VLPs have been exploited for different biomedical applications, such as vaccines, drug delivery and nanomaterials [3-5]. However, in this production strategy, capsid proteins are expressed and concomitantly assembled into VLPs inside the host cells, which may encapsidate host-related contaminations and thus impede VLP use [6,7].

Along with progress in understanding virus assembly requirements, in vitro VLP production based on various viruses had been established. For the in vitro assembly, the capsid proteins are expressed and purified from expression hosts or cell-free protein synthesis systems (CFPS), or the proteins are obtained from in vivo VLPs via a disassembly procedure. This avoids trapping host-derived impurities, a potential source for unwanted immune response. Next, the capsid proteins are incubated under defined chemical conditions which promote VLP assembly. Compared to the in vivo VLPs, the in vitro technology offers the possibility to mix different capsid proteins or epitopes within a particle, for example resulting in a vaccine candidate for different viral genotypes $[8,9]$. For therapeutic delivery applications, the in vitro technology also enables the possibility to mix and match as well as control the amounts of different payloads during the capsid assembly reaction [4].

There are a few literature reviews on VLPs that focus on production [10] and various applications [3-5,11], but these do not discriminate between in vivo and in vitro VLPs. Here, we focus on in vitro produced VLPs covering the three domains: capsid-protein production, in vitro VLP formation and VLP characterization. We report in vitro VLP 
assembly protocols that have been applied in the context of vaccine development and drug delivery.

\section{In Vitro Assembly of Virus-Like Particles (VLPs)}

\subsection{Capsid Protein Production}

To prepare protein monomers for a cell-free capsid assembly under defined and controllable conditions, viral capsid protein can be obtained either by expression and purification of non-assembled proteins or via a disassembly procedure from in vivo generated and purified VLPs. The choice of the hosts for capsid protein expression significantly affects all further steps. E. coli is a preferred host for high capsid-protein expression [12]. Depending on the viral protein structure and expression method, proteins are either expressed in soluble form, which is normally favorable for capsid assembly, or as aggregates forming inclusion bodies within E. coli. To increase the soluble protein yield during expression, different factors such as the choice of the $E$. coli strain, expression vector, codon usage, expression temperature, induction condition and medium can be optimized $[10,13]$. Furthermore, tags have been fused to viral protein termini at the genetic level to aid protein folding and/or purification. Taking into account that the additional tag may interfere with capsid formation, a protease cleavage site can be added and used prior to assembly [14-16]. If proteins tend to form inclusion bodies in E. coli owing to incorrect folding, this expression strategy may be exploited with a strong promoter to produce high yields per dry mass and ease initial purification. The inclusion bodies can be easily separated from the cell debris and solubilized using strong denaturants like $6 \mathrm{M}$ guanidinium $\mathrm{HCl}$ or 6-8 $\mathrm{M}$ urea [17-21].

Other favorable hosts for capsid protein production are Sf9 insect cells in combination with baculovirus vectors and yeast. Both organisms are amenable to scale up and offer the advantage of eukaryotic post-translational protein modification [22-24]. Lastly, cell-free protein synthesis systems have also been used to produce viral capsid proteins in defined transcription/translation reactions. This method allows for a direct control of capsid protein expression and VLP assembly conditions and enables production of toxic and insoluble proteins [25-28].

If VLPs assemble spontaneously inside the expression hosts, they may contain undesired compounds. To obtain protein subunits from VLPs formed inside the host cell, different disassembly methods exist. Bacteriophage MS2 VLPs produced in E. coli were disassembled at low $\mathrm{pH}$, while human papillomavirus (HPV) VLPs obtained from insect cells were dissociated with carbonate buffer at pH 9.6 [29,30]. Cowpea chlorotic mottle virus (CCMV) particles assembled in plants were denatured in a neutral buffer with high salt concentration [31-33]. Urea is commonly used to disassemble the formed VLPs. Bacteriophage $Q \beta$ VLPs were disassembled in $6 \mathrm{M}$ urea [34], whereas $2.5 \mathrm{M}$ urea were sufficient to denature hepatitis $B$ core protein $(\mathrm{HBc})$ VLPs [35]. Reducing and chelating agents can also be used in VLP disassembly [30,36-41].

\subsection{Factors Impacting In Vitro Assembly}

The capsid self-assembly is driven by Brownian motion and interactions between subunits as well as subunits and other viral or non-viral components to minimize free energy in higher structures. The capsid assembly is proposed to occur in three steps. First, a capsid oligomer nucleus is formed from capsid proteins in the so-called nucleation phase. Afterwards, building blocks (a protein monomer, or capsid oligomers) are added to the nucleus during the growth phase. Finally, the last building block is inserted to complete the capsid [42-44]. The assembly process is complicated and highly dependent on the viral protein structure and the experimental conditions. Conceptually, VLP formation in the first place is governed by general rules applicable to protein folding and stability while considering aggregation [45]. We present here the main factors that affect in vitro assembly (Figure 1). 


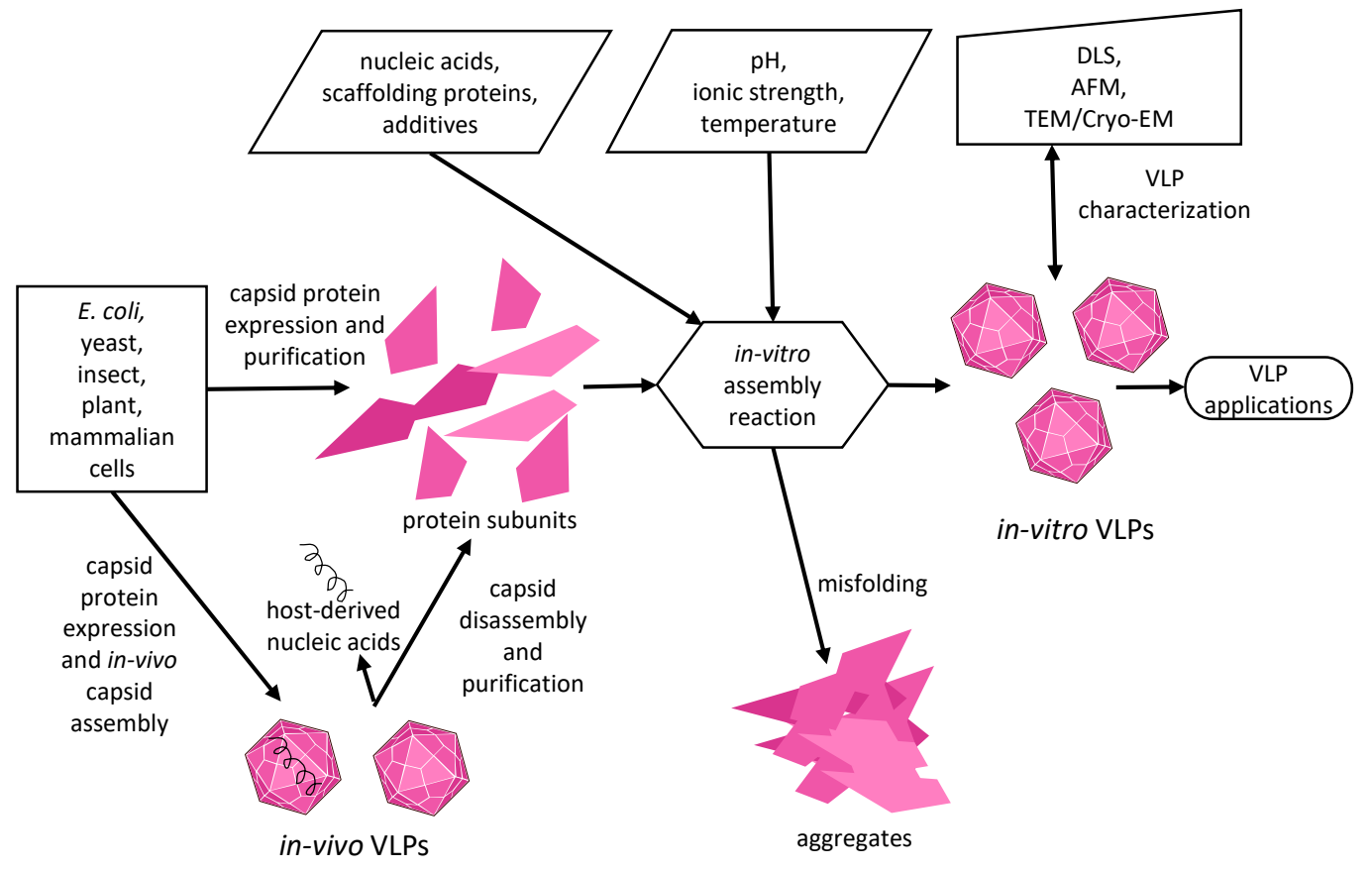

Figure 1. Schematic representation of in vitro virus-like particle (VLP) assembly. Capsid protein production methods, factors impacting on VLP in vitro assembly and typical methods to characterize VLPs are presented.

\subsection{1. $\mathrm{pH}$, Ionic Strength, and Temperature}

$\mathrm{pH}$ plays an important role for in vitro assembly since it affects the capsid-protein charge. Most in-vitro assembly reactions were optimized at a physiological $\mathrm{pH}[15,18,46]$. Interestingly, some particles assemble at acidic or alkaline $\mathrm{pH}$. In vitro assembly studies of CCMV showed that the attraction between capsid proteins was optimal at about $\mathrm{pH} 5$ and decreased sharply with increasing $\mathrm{pH}$ [47]. Rotavirus (RV) VLPs formed in vitro at an acidic $\mathrm{pH}$ [21]. Our in vitro assembly results from adeno-associated virus serotype 2 (AAV2), however, indicated that an alkaline $\mathrm{pH}(\mathrm{pH} 9)$ was most suitable to avoid aggregates and promote VLP formation [19].

Ionic strength is another main factor for capsid assembly in vitro. Salts interact with charges on the protein surface, influence the water shell, disfavor hydrophobic exposure and ultimately affect protein stability [48]. To optimize in vitro capsid-assembly reactions, ionic strength needs to be optimized along with the change of $\mathrm{pH}[15,18,46]$, which can be presented as phase diagrams of the protein assembly [49].

The effect of temperature on the capsid assembly also deserves evaluation. Low temperatures are normally favorable as they reduce protein aggregation and chemical degradation. For example, the in vitro assembly of primate erythroparvovirus 1 (B19) at $4{ }^{\circ} \mathrm{C}$ showed a better yield at $4{ }^{\circ} \mathrm{C}$ than at $37^{\circ} \mathrm{C}$ [18]. Contrarily, near-physiological temperatures promoted the Rous Sarcoma virus capsid formation in vitro [50]. Another report on hepatitis virus assembly revealed that subunit exchange with assembled capsid shells was generally slow but slightly elevated at lower temperature [51].

\subsubsection{Nucleic Acids, Scaffolding Protein, and Additives}

The in vitro assembly of some capsids was highly influenced by the presence of nucleic acids. CCMV, a single-stranded RNA virus, is a well-studied model. Garmann et al. demonstrated that the assembly of CCMV depends on balanced capsid protein (CP)-CP interactions relative to $\mathrm{CP}-\mathrm{RNA}$ interactions [52]. Furthermore, a high CP/RNA mass ratio is required to assemble CCMV VLPs [53]. Recently, CCMV capsid proteins were shown to encapsidate both single-stranded DNA (ssDNA) in typical spherical assemblies and doublestranded DNA (dsDNA) in rod-like VLPs [54]. Other RNA viruses also require nucleic acids 
for in vitro assembly. The assembly of Gag proteins into human immunodeficiency virus (HIV1) VLPs in a defined system was directly supported by RNA [55]. Similarly, the invitro assembly of hepatitis $\mathrm{C}$ virus (HCV) nucleocapsid-like particles required structured RNA as reported by Kunkel et al. [56]. Bacteriophage MS2 was also assembled in vitro in the presence of nucleic acids [29]. The assembly of beak and feather disease virus (BFDV), a member of the circular ssDNA circovirus family, is regulated by its ssDNA genomes. The highly positive charged N-terminal arginine-rich motif of capsid proteins interacted with ssDNA during in vitro capsid assembly [57]. VLPs derived from simian virus 40 (SV40), a dsDNA virus, also needed DNA for efficient in vitro assembly [58]. Nonetheless, it should be considered that the additional nucleic acids within the in vitro VLPs might interfere with VLP applications. For example, nucleic acid can modulate the immune response by activating pattern recognition receptor (PRR) [6].

Scaffolding proteins are not a component of a mature capsid. These proteins assist during capsid formation. Providing a scaffolding protein to an in vitro capsid assembly in many cases increases the yield of fully assembled capsids. Our data on in vitro assembly of AAV2 showed that the addition of assembly-activating protein (AAP, an AAV scaffolding protein) helped to improve AAV2 capsid formation [19]. The assembly of different bacteriophages was highly dependent on scaffolding proteins, which promoted the polymerization of the major capsid protein [59-63]. The herpes simplex virus procapsid assembly reaction from purified major capsid proteins has been reported by Newcomb et al. to require a scaffolding protein and to form small procapsids at low concentrations of the scaffolding protein [64].

Small molecule additives can be used to aid capsid assembly. L-arginine improved the solubility of assembled VLPs by preventing aggregation during protein refolding $[19,65]$. In a study performed by Lampel et al., chemical chaperones, such as methylamines enhanced HIV-1 in vitro assembly [66]. Other reagents can be combined with capsid proteins during in vitro assembly leading to new hybrid materials. For example, CCMV capsid proteins have been explored in combination with different supramolecular templates. Organo $\mathrm{Pt}$ (II) complexes formed spherical or rod-like structures that were combined with the capsid proteins to form likewise shaped CCMV VLPs [67]. Micelles and DNA micelles were packaged inside CCMV VLPs that offer new drug-delivery systems, especially for hydrophobic drugs $[68,69]$. Polymers were also incorporated into CCMV VLPs during in vitro assembly $[70,71]$.

\subsection{VLP Characterization}

To analyze the formed in vitro VLPs, different biochemical and biophysical methods can be applied. Standard methods are sodium dodecyl sulfate-polyacrylamide gel electrophoresis (SDS-PAGE) to determine size and purity, Western blot to confirm the identity, and ultraviolet (UV) spectroscopy with light scattering compensation, which monitors amino acids (phenylalanine, tyrosine and tryptophan) and nucleotides with an absorbance spectrum of about 240-300 nm, to determine concentrations [36,72,73]. Other protein quantitation methods, such as the bicinchoninic acid (BCA) assay and Bradford assay have been also used $[18,36,74]$. Size exclusion chromatography and dynamic light scattering (DLS) are widely used to characterize the size of VLPs [19,75-77]. The latter method provides the heterogeneity of the VLP samples and the mean hydrodynamic diameter of particles, which is normally greater than the physical diameter. Stability has been assessed using techniques such as differential scanning fluorimetry [78]. Structural integrity has been verified by circular dichroism spectroscopy (CD) and Fourier-transform infrared (FT-IR) spectroscopy [79]. The nucleic-capsid protein interactions have been determined by gel retardation assay, optical tweezers (OT) and acoustic force spectroscopy (AFS) [53,58]. VLP morphology and possible intermediate aggregates formed during an in-vitro assembly reaction can be visualized using transmission electron microscopy (TEM) or atomic force microscopy (AFM). TEM can also be used to distinguish between empty and encapsulated VLPs [52,59] and AFM can assess the VLP height profile [19,80,81]. A VLP high-resolution 
structure can be determined using Cryo-EM [52] or crystallography [82]. Mass spectrometry has been used to identify VLP composition [76]. If available, an assembled particle antibody helps to confirm VLP conformation in enzyme-linked immunosorbent assays (ELISAs) [19].

Understanding capsid self-assembly pathways will help to tailor the mechanisms of virus infection and replication for therapeutic applications. Different methods have been used to characterize intermediate assemblies and the assembly pathways of virus capsids, such as electron microscopy [83-86], X-ray crystallography [57], atomic force microscopy [57,58,85], small-angle X-ray scattering [87-92], mass spectrometry [93-95], size-exclusion chromatography [84], resistive-pulse sensing [84,96], interferometric scattering microscopy [97], single-molecule fluorescence correlation spectroscopy [98], optical tweezers in combination with confocal fluorescence microscopy and acoustic force spectroscopy $[58,99]$. Recently, high-speed atomic force microscopy (HS-AFM), a powerful single-molecule technique for real-time visualization of biomolecules in dynamic action [100], has been used to visualize self-assembly of HIV capsid protein lattice [81]. This physical virology technique will enable real-time capsid assembly studies of other viruses in the future.

\section{Application of In Vitro-Assembled VLPs}

\subsection{Vaccine Development}

VLPs are composed of protein monomer units in a repetitively ordered structure with a size range of $20-200 \mathrm{~nm}$ in diameter that is appropriate for vaccination [11]. VLPs are able to induce a strong immune response, which was described by Jennings et al. and Mohsen et al. [6,101]. A VLP derived from a pathogenic virus may be used to elicit an immune response directly to the parental virus, or function as a scaffold to present heterologous epitopes. Compared to subunit peptides or proteins, VLPs provide the possibility to present epitopes in a natural conformation that benefits an anti-viral B- and T-cell immune response. Moreover, due to the highly repetitive epitope presentation, VLPs can induce a strong B cell response even without adjuvants [102-104]. Another advantage is that a foreign epitope can be chemically or genetically incorporated onto the VLP surface, offering a flexible platform to create different vaccine candidates [105-108].

A few VLP-based vaccines have a long and very successful tradition in the clinic and recently several new candidates progressed to the clinic. These vaccine candidates have been produced in vivo or by an in vitro system [3]. Compared to in vivo VLP production, which potentially may be contaminated with host-derived components resulting in unpredictable immune responses that require an additional quality control effort [6], a cell-free VLP technology offers better control during production. A list of developed and approved vaccine candidates is presented in Table 1.

Table 1. In vitro produced VLP-based vaccines on the market or in development.

\begin{tabular}{|c|c|c|c|c|c|c|}
\hline $\begin{array}{c}\text { Vaccine } \\
\text { Candidate }\end{array}$ & Host & $\begin{array}{c}\text { VLP a } \\
\text { Platform }\end{array}$ & $\begin{array}{c}\text { Vaccine Antigen } \\
\text { Proteins }\end{array}$ & Assembly Method & $\begin{array}{l}\text { Development } \\
\text { Stage }\end{array}$ & Ref. \\
\hline $\begin{array}{c}\text { Cervarix } \\
\text { (GlaxoSmithKline) }\end{array}$ & $\begin{array}{l}\text { Insect } \\
\text { cell }\end{array}$ & HPV-L1 & HPV 16 and 18 L1 & $\begin{array}{l}\text { Multi-step } \\
\text { purification }\end{array}$ & Approved & [109] \\
\hline $\begin{array}{l}\text { Gardasil } \\
\text { (Merck Sharp } \\
\text { and Dohme) }\end{array}$ & Yeast & HPV-L1 & HPV 6/11/16/18 L1 & $\begin{array}{c}\text { VLP disassembly } \\
\text { using } \\
\text { DTT/Reassembly } \\
\text { by DTT removal }\end{array}$ & Approved & [79] \\
\hline $\begin{array}{l}\text { Gardasil-9 } \\
\text { (Merck Sharp } \\
\text { and Dohme) }\end{array}$ & Yeast & HPV L1 & $\begin{array}{c}\text { HPV } \\
\text { 6/11/16/18/31/33/45/52/58 } \\
\text { L1 }\end{array}$ & $\begin{array}{l}\text { VLP disassembly } \\
\text { using } \\
\text { DTT/Reassembly } \\
\text { by DTT removal }\end{array}$ & Approved & [110] \\
\hline $\begin{array}{l}\text { Cecolin }^{\circledR} \\
\text { (Innovax) }\end{array}$ & E. coli & HPV L1 & HPV16 and 18 L1 & $\begin{array}{l}\text { Protein purification } \\
\text { and reducing } \\
\text { agent removal }\end{array}$ & $\begin{array}{l}\text { Approved } \\
\text { (China) }\end{array}$ & {$[8,111]$} \\
\hline
\end{tabular}


Table 1. Cont.

\begin{tabular}{|c|c|c|c|c|c|c|}
\hline $\begin{array}{c}\text { Vaccine } \\
\text { Candidate }\end{array}$ & Host & $\begin{array}{l}\text { VLP a } \\
\text { Platform }\end{array}$ & $\begin{array}{l}\text { Vaccine Antigen } \\
\text { Proteins }\end{array}$ & Assembly Method & $\begin{array}{l}\text { Development } \\
\text { Stage }\end{array}$ & Ref. \\
\hline $\begin{array}{l}\text { HPV 9-valent } \\
\text { (Innovax) }\end{array}$ & E. coli & HPV L1 & $\begin{array}{c}\mathrm{HPV} \\
6 / 11 / 16 / 18 / 31 / 33 / 45 / 52 / 58 \\
\text { L1 }\end{array}$ & $\begin{array}{l}\text { Protein purification } \\
\text { and reducing } \\
\text { agent removal }\end{array}$ & $\begin{array}{l}\text { Phase } 2 \\
\text { NCT03935204 }\end{array}$ & [9] \\
\hline $\begin{array}{l}\text { Hecolin }^{\circledR} \\
\text { (Innovax) }\end{array}$ & E. coli & HEV p239 & HEV truncated E2, 239 a.a. & $\begin{array}{l}\text { Multi-step } \\
\text { purification }\end{array}$ & $\begin{array}{l}\text { Approved } \\
\text { (China) }\end{array}$ & [78,112-114] \\
\hline $\mathrm{HEV}$ & E. coli & HEV p495 & HEV E2, 495 a.a. & $\begin{array}{c}\text { Protein was } \\
\text { dialyzed into } \\
50 \mathrm{mM} \text { phosphate } \\
\text { buffer with } 0.5 \mathrm{M} \\
\mathrm{NaCl}, \mathrm{pH} 6.5\end{array}$ & $\begin{array}{l}\text { Preclinical } \\
\text { evaluation }\end{array}$ & [115] \\
\hline $\begin{array}{c}\text { ENGERIX- } \\
\text { B/Fendrix } \\
\text { (GlaxoSmithKline) }\end{array}$ & Yeast & HBsAg & HBV HBsAg & $\begin{array}{l}\text { Multi-step } \\
\text { purification }\end{array}$ & Approved & {$[116,117]$} \\
\hline $\begin{array}{l}\text { Recombivax } \\
\text { (Merck Sharp } \\
\text { and Dohme) }\end{array}$ & Yeast & HBsAg & HBV HBsAg & $\begin{array}{l}\text { Multi-step } \\
\text { purification }\end{array}$ & Approved & {$[118,119]$} \\
\hline Hepatitis B & $\begin{array}{l}\text { Cell-free } \\
\text { synthesis } \\
\text { system }\end{array}$ & $\mathrm{HBcAg}$ & $\mathrm{HBV}$ truncated $\mathrm{HBcAg}$ & $\begin{array}{l}30 \mu \mathrm{L} \mathrm{CFPS} \mathrm{product} \\
\text { was dialyzed } \\
\text { against } 100 \mathrm{mM} \\
\mathrm{HEPES} \text { and } 200 \mathrm{mM} \\
\mathrm{NaCl} \text { pH } 7 \\
1 \mathrm{~mL} \mathrm{CFPS} \mathrm{product} \\
\text { was dialyzed } \\
\text { against } 10 \mathrm{mM} \\
\text { BisTris and } 0.385 \mathrm{M} \\
\mathrm{NaCl}, \mathrm{pH} 5.5\end{array}$ & $\begin{array}{l}\text { Preclinical } \\
\text { evaluation }\end{array}$ & [27] \\
\hline $\begin{array}{l}\text { SARS-CoV-2 } \\
\text { (NVX-CoV2373, } \\
\text { Novavax) }\end{array}$ & $\begin{array}{l}\text { Sf9 } \\
\text { cell }\end{array}$ & $\begin{array}{c}\text { S-trimer } \\
\text { nanoparticle }\end{array}$ & SARS-CoV-2 Spike & $\begin{array}{l}\text { Removal of the } \\
\text { detergent } \\
\text { (Tergitol }^{\mathrm{TM}} \text { NP-9) } \\
\text { during protein } \\
\text { purification }\end{array}$ & $\begin{array}{c}\text { Phase } 3 \\
\text { NCT04611802 }\end{array}$ & {$[77,120]$} \\
\hline $\begin{array}{l}\text { MERS-CoV and } \\
\text { SARS-CoV } \\
\text { (Novavax) }\end{array}$ & Sf9 cell & S nanoparticle & MERS-CoV/SARS-CoV Spike & $\begin{array}{c}\text { Removal of } \\
\text { the detergent } \\
\text { (Tergitol }{ }^{\mathrm{TM}} \text { NP-9) } \\
\text { during protein } \\
\text { purification }\end{array}$ & $\begin{array}{l}\text { Preclinical } \\
\text { evaluation }\end{array}$ & {$[121]$} \\
\hline $\begin{array}{l}\text { Influenza } \\
\text { (NanoFlu } \\
\text { Novavax })\end{array}$ & Sf9 cell & $\begin{array}{c}\text { HA } \\
\text { nanoparticle }\end{array}$ & Influenza virus HA & $\begin{array}{c}\text { Removal of } \\
\text { the detergent } \\
\text { (TergitolTM NP-9) } \\
\text { during protein } \\
\text { purification }\end{array}$ & $\begin{array}{c}\text { Phase 1/2 } \\
\text { NCT04120194 }\end{array}$ & {$[122,123]$} \\
\hline RSV (Novavax) & Sf9 cell & F nanoparticle & RSV F & $\begin{array}{c}\text { Removal of } \\
\text { the detergent } \\
\text { (TergitolTM NP-9) } \\
\text { during protein } \\
\text { purification }\end{array}$ & $\begin{array}{c}\text { Phase } 1 \\
\text { NCT03026348 }\end{array}$ & {$[23,124,125]$} \\
\hline RSV & E. coli & B19 VP2 & $\begin{array}{l}\text { Two peptides derived from } \\
\text { RSV F }\end{array}$ & $\begin{array}{c}\text { Denatured proteins } \\
\text { in } 5 \mathrm{M} \mathrm{GuHCl} \text { were } \\
\text { dialyzed into PBS } \\
\text { buffer at } 4{ }^{\circ} \mathrm{C} \text { for } \\
36 \mathrm{~h}\end{array}$ & $\begin{array}{l}\text { Preclinical } \\
\text { evaluation }\end{array}$ & {$[126]$} \\
\hline CPV & E. coli & CPV VP2 & CPV VP2 & $\begin{array}{c}\text { Fusion proteins } \\
\text { (SUMO tag fused to } \\
\text { capsid protein) were } \\
\text { cleaved by SUMO } \\
\text { protease and } \\
\text { dialyzed into } \\
50 \mathrm{mM} \text { Tris-HCl, } \\
150 \mathrm{mM} \mathrm{NaCl}, \mathrm{pH} 7\end{array}$ & $\begin{array}{l}\text { Preclinical } \\
\text { evaluation }\end{array}$ & {$[15]$} \\
\hline
\end{tabular}

a B19: Erythroparvovirus 1; CPV: Canine parvovirus; HBcAg: Hepatitis B core antigen; HBsAg: the surface antigen of the Hepatitis B virus; HBV: Hepatitis B virus; HEV: Hepatitis E Virus; HPV: Human papillomavirus; MERS: Middle East respiratory syndrome coronavirus; RSV: Respiratory syncytial virus; SARS: Severe acute respiratory syndrome coronavirus; SARS-CoV-2: Severe acute respiratory syndrome coronavirus type 2; HEPES: 2-[4-(2-hydroxyethyl)piperazin-1-yl]ethanesulfonic acid. 
Human papillomavirus (HPV) is a major cause of cervical cancer and associates with many human diseases [127]. HPV capsids are composed of two capsid proteins, L1 and $\mathrm{L} 2$, assembled in a T = 7 icosahedral structure (about $60 \mathrm{~nm}$ in diameter) [128]. L1 is a structural protein and able to form HPV VLPs [129]. To date, there are four HPV vaccines on the market, which use L1-VLP platforms [3].

The HPV vaccine Cervarix, which is manufactured by GlaxoSmithKline and partially based on technology from MedImmune/AstraZeneca, was approved in 2007 in the European Union (EU) and other countries and 2009 in the USA. It contains two monovalent antigen bulks of C-terminally truncated versions of the major capsid proteins L1 of either serotype 16 or 18. The proteins are produced in cells derived from the Trichoplusia ni (Hi-5) insect cell line with recombinant baculoviruses encoding the L1 proteins. The proteins are released by osmotic shock and upon a multi-step purification by filtration and chromatography the proteins assemble into spherical particles, which are mixed and formulated with adjuvant. The final product dose contains $20 \mu \mathrm{g}$ HPV $16 \mathrm{~L} 1$ protein, $20 \mu \mathrm{g} \mathrm{HPV} 18$ L1 protein, $500 \mu \mathrm{g}$ aluminium hydroxide, $50 \mu \mathrm{g}$ 3-O-desacyl-4' ${ }^{\prime}$-monophosphoryl lipid A (MPL) and $0.624 \mathrm{mg} \mathrm{NaH} \mathrm{PO}_{4} \cdot 2 \mathrm{H}_{2} \mathrm{O}$ [109].

The HPV vaccine Gardasil, which is produced by Merck Sharp and Dohme and was approved in the USA in 2010, contains the HPV L1 protein from serotypes 6, 11, 16, and 18. The vaccine Gardasil 9 (9-valent vaccine), which was approved in the USA in 2014, additionally contains the HPV L1 proteins of serotypes of 31, 33, 45, 52, and 58. The proteins are individually produced in the yeast from Saccharomyces cerevisiae transformed with the pGAL110 expression vector coding for the respective proteins. Cells are harvested by filtration, frozen and then VLPs are released by homogenization. For some L1 types (31, 33, $45,52,58)$, a protease inhibitor is added. Purification comprises cross-flow membrane filtration for debris removal, cation exchange chromatography for host cell protein removal, and hydoxyapatite chromatography for polishing and enrichment of monodisperse VLPs. For all but type L1 serotype 18, the VLPs are disassembled using dithiothreitol (DTT) and reassembled by removing DTT, which improves VLP structure and stability. A final buffer exchange yields the final aqueous products which are then adsorbed onto the adjuvant amorphous aluminium hydroxyphosphate sulfate by in-line mixing. The individual products are then mixed by sequentially adding them to a tank with buffer and alum adjuvant, settling and decanting. The final $0.5 \mathrm{~mL}$ aqueous dose Gardasil 9 contains $30 \mu \mathrm{g}$ L1 6 , $40 \mu \mathrm{g} \mathrm{L1} 11,60 \mu \mathrm{g} \mathrm{L1} 16,40 \mu \mathrm{g}$ L1 18, and $20 \mu \mathrm{g}$ of L1 31, 33, 45, 52, 58 as well as $500 \mu \mathrm{g}$ aluminium (adjuvant as amorphous aluminium hydroxyphosphate sulfate), $9.56 \mathrm{mg} \mathrm{NaCl}$ (for stability), $0.78 \mathrm{mg}$ L-histidine (for buffering), $50 \mu \mathrm{g}$ polysorbate 80 (for VLP stability and prevention of aggregation or surface adsorption), $35 \mu \mathrm{g}$ Na-borate (for buffering) $[79,110]$.

As a biosimilar, the company Innovax produced Cecolin, a bivalent HPV16 and HPV18 vaccine, by expressing the respective L1 proteins in E. coli and maintaining them in soluble pentamer form under a reducing condition (20 mM DTT). The HPV VLPs were formed by removal of the reductant during protein purification [8]. The vaccine production in E. coli offers a low manufacturing cost and easy scale-up compared to other licensed products [111]. Similarly, Innovax produced an HPV9-valent vaccine candidate (HPV 6/11/16/18/31/33/45/52 and 58), which is currently in phase 2 clinical trial [9]. As a result of protein expression in E. coli, lipopolysaccharide (LPS) might contaminate into VLPs that can enhance immune responses and cause pyrogenic and shock reactions in mammals. To reduce LPS contamination, different methods, such as size exclusion chromatography, affinity chromatography, binding to polymyxin and treatment with Triton $\mathrm{X}-114$ have been used [130].

Hepatitis E virus (HEV), which can be quasi-enveloped, is the most acute hepatitis cause in both developing and developed countries [131,132]. A 7.5-kb HEV genome comprises three overlapping open reading frames encapsidated into a $\mathrm{T}=3$ symmetry capsid of 27-34 nm in diameter [133,134]. The open reading frame 2 (ORF2) codes for viral capsid proteins, which were produced in E. coli or insect cells as recombinant HEV vaccine candidates [135]. Hecolin, a licensed HEV vaccine in China, is an HEV cell-free 
assembly product [113]. p239 truncated capsid protein (239 amino acid (a.a.) of a fulllength capsid protein with 660 a.a.) was obtained from E. coli and assembled into VLPs of 20-30 nm diameter via multiple purification steps [78,112]. Another HEV vaccine candidate is currently under preclinical evaluation using p495 protein (495 a.a. truncated capsid protein) expressed in E. coli to form in vitro HEV VLPs [115].

Also surface antigens from enveloped viruses have been used in mostly defined assembly reactions. The surface antigen of the hepatitis B virus (HBV) which causes chronic infection of about $3.5 \%$ world population [136] named HBsAg was recombinantly produced in yeast. In a first version, the $\mathrm{S}$ gene of $\mathrm{HBV}$ was cloned in a plasmid and expressed in Saccharomyces cerevisiae strain DC5. Purification steps comprised cell disruption, diafiltration, size exclusion chromatography, ion-exchange chromatography, a $\mathrm{CsCl}$ ultracentrifugation followed by a final size exclusion chromatography. In the absence of chemical treatment, HBsAg formed spheres of about 20-22 nm containing non-glycosylated HBsAg and a lipid matrix consisting mainly of phospholipids [116,117]. This vaccine is marketed by GlaxoSmithKline as ENGERIX B, which was approved in 1986 in the EU as the first recombinant vaccine, and with added MPL adjuvant as Fendrix, which was approved in 2005. A similar product also produced in yeast is Recombivax HB from Merck $[118,119]$. The malaria vaccine Mosquirix from GlaxoSmithKline, which is also named RTS,S/AS01 and was approved in the EU in 2015, is produced by coexpression in yeast of the HBsAg with a fusion protein of HBsAg with the pre-erythrocytic circumsporozoite protein (CSP) of the Plasmodium falciparum malaria parasite. In this case, the mixed particles formed already during expression [137]. Hence, for these multi-subunit particles formed by surface antigens of enveloped viruses, which do not resemble typical capsids but defined aggregates, the differentiation between in-cell versus in-buffer VLP assembly is fluid. Compared to in vivo VLPs, the in vitro manufacturing process is defined by additional steps to reassemble VLPs outside the cells. In some cases, a dedicated assembly step is missing, because the in vitro VLP assembly occurs during steps ascribed to purification (Assembly method, Table 1). Such combined purification and assembly may reduce downstream processing costs. In other cases, few mutations may shift assembly between in vivo and in vitro.

Recently, the company Novavax developed the NVX-CoV2373 vaccine candidate (currently in phase 3 clinical trial) for preventing severe acute respiratory syndrome coronavirus 2 (SARS-CoV-2) infection, the virus which spread from China around the globe in 2020 causing the coronavirus disease 2019 (COVID-19) pandemic with millions of infections and deaths $[120,138]$. The SARS-CoV-2 spike protein (S protein), which is responsible for receptor binding and virus entry [139] was expressed in Sf9 insect cells using a baculovirus expression system. The protein was then obtained from the plasma membranes with a buffer containing NP-9 detergent. The $27.2 \mathrm{~nm}$ nanoparticles, potentially S-trimers anchored within polysorbate 80 (PS80) detergent cores, formed during protein purification and, concomitantly, detergent removal [77]. This strategy was also used to develop vaccine candidates against other coronaviruses (SARS, Middle East respiratory syndrome (MERS)) [121] and other pathogens including Influenza virus [122,123] and respiratory syncytial virus (RSV) $[23,124,125]$.

Other vaccine candidates with different in-vitro assembly conditions are under preclinical evaluation. The C-terminally truncated hepatitis B core antigen $(\mathrm{HBcAg})$ was produced using E. coli-based cell-free protein synthesis reaction and assembled into HBV VLPs [27]. The primate erythroparvovirus 1 (B19) VLPs presenting the peptides derived from F proteins of RSV virus were tested as an RSV vaccine candidate. The chimeric proteins were expressed in inclusion bodies in E. coli, and the VLPs were formed by dialyzing of the proteins from a denaturing buffer $(5 \mathrm{M} \mathrm{GuHCl})$ to PBS buffer [126]. A vaccine candidate for canine parvovirus (CPV) disease was also produced via an in vitro cell-free reaction. $\mathrm{Xu}$ et al. reported that $\mathrm{CPV}$ capsid protein (VP2) fused to a SUMO-tag was acquired from E. coli in soluble form. The CPV VLPs were developed during SUMO tag removal and dialysis of the capsid proteins into a physiological buffer [15]. 


\subsection{Therapeutic Delivery}

VLPs are attractive candidates to deliver drugs, small molecules or nucleic acids due to their biocompatibility, biodegradability and targeted delivery [4,140]. Different cargo-loading strategies have been explored with both in vivo and in vitro VLPs [141]. Here, we focus on different in vitro packaging approaches, which occur via disassembly/reassembly of VLPs or during in vitro assembly of purified proteins into VLPs. The in vitro encapsulation mainly relies on the interactions between loading cargoes and viral capsid proteins and differs among VLPs (Table 2). With small molecules not interfering with the assembly, concentration-dependent stochastic loading by engulfment during assembly is also feasible [142].

Table 2. In vitro VLP delivery platforms.

\begin{tabular}{|c|c|c|c|c|c|}
\hline $\begin{array}{c}\text { VLP } \\
\text { Platform }\end{array}$ & $\begin{array}{l}\text { Expression } \\
\text { System }\end{array}$ & $\begin{array}{c}\text { Cargo and } \\
\text { Loading Method }\end{array}$ & Targeting & Assembly Method & Ref. \\
\hline MS2 & E. coli & $\begin{array}{l}\text { Chemotherapeutic } \\
\text { drugs (DOX), siRNA } \\
\text { cocktails, protein toxins } \\
\text { Conjugated to RNA }\end{array}$ & $\begin{array}{l}\text { Hepatocellular } \\
\text { carcinoma using } \\
\text { SP94 peptide }\end{array}$ & $\begin{array}{c}\text { VLP disassembly in glacial acetic } \\
\text { acid/Reassembly and packaging: } \\
\text { capsid proteins in } 10 \mathrm{mM} \text { acetic acid, } \\
50 \mathrm{mM} \mathrm{NaCl} \text {, pH } 4 \text { were incubated } \\
\text { with RNA in } 50 \text { mM Tris-HCl } \\
\text { pH } 8.5 \text { buffer }\end{array}$ & [29] \\
\hline MS2 & E. coli & $\begin{array}{c}\text { siRNA } \\
\text { Genetic fusion to TR } \\
\text { step loop }\end{array}$ & $\begin{array}{l}\text { HeLa cells using } \\
\text { human transferrin }\end{array}$ & $\begin{array}{l}\text { VLP disassembly in glacial acetic } \\
\text { acid/ Reassembly and packaging in } \\
40 \text { mM ammonium acetate, } \\
\text { pH } 6 \text { buffer }\end{array}$ & [143] \\
\hline MS2 & E. coli & $\begin{array}{l}\text { Alkaline phosphatase } \\
\text { Electrostatic interaction } \\
\text { to capsid protein }\end{array}$ & - & $\begin{array}{l}\text { VLP disassembly in glacial acetic } \\
\text { acid/Reassembly and protein } \\
\text { packaging in } 50 \mathrm{mM} \text { Tris, } 100 \mathrm{mM} \\
\mathrm{NaCl}, 250 \mathrm{mM} \text { Trimethylamine } \\
\quad \mathrm{N} \text {-oxide buffer }\end{array}$ & [76] \\
\hline $\mathrm{P} 22$ & E. coli & $\begin{array}{l}\text { Streptavidin, } \\
\text { Ferritin cages, CelB } \\
\text { Genetic fusion to a } \\
\text { scaffold protein (SP) }\end{array}$ & - & $\begin{array}{l}\text { VLP disassembly in } 3 \mathrm{M} \\
\mathrm{GuHCl} / \text { Reassembly and protein } \\
\text { packaging by adjusting the mixture of } \\
\text { coat proteins }(\mathrm{CP}) \text { and fusion proteins } \\
\text { to } 1.5 \mathrm{M} \mathrm{GuHCl} \text {, and dialyzing to the } \\
\text { buffer of } 50 \mathrm{mM} \text { Tris- } \mathrm{HCl}, 25 \mathrm{mM} \\
\mathrm{NaCl}, 2 \mathrm{mM} \text { EDTA, } 3 \mathrm{mM} \\
\beta \text {-mercaptoethanol, } 1 \% \text { glycerol }\end{array}$ & {$[144,145]$} \\
\hline$Q \beta$ & E. coli & $\begin{array}{l}\text { Fluorescent protein } \\
\qquad(\mathrm{GFP})\end{array}$ & - & $\begin{array}{c}\mathrm{Q} \beta \text { VLPs disassembly in } 20 \mathrm{mM} \\
\text { Tris-HCl, } 50 \mathrm{mM} \mathrm{NaCl}, 6 \mathrm{M} \text { urea, } \\
10 \mathrm{mM} \text { DTT, and dialyzed against } \\
10 \mathrm{mM} \text { acetic acid and } 50 \mathrm{mM} \\
\mathrm{NaCl} / \text { Reassembly and GFP } \\
\text { packaging in } 50 \mathrm{mM} \mathrm{NaCl}, 20 \mathrm{mM} \\
\text { Tris- } \mathrm{HCl}, \mathrm{pH} 7.5\end{array}$ & {$[34]$} \\
\hline $\mathrm{HBc}$ & E. coli & $\begin{array}{c}\text { DOX } \\
\text { Insertion of hydrophobic } \\
\text { peptide to capsid } \\
\text { protein to confine DOX }\end{array}$ & $\begin{array}{l}\text { Tumor-targeting } \\
\text { peptide RGD }\end{array}$ & $\begin{array}{c}\text { VLP disassembly in } 2.5 \mathrm{M} \text { urea, } \\
150 \mathrm{mM} \mathrm{NaCl}, 50 \mathrm{mM} \\
\text { Tris- } \mathrm{HCl} / \text { Reassembly and DOX } \\
\text { packaging in the buffer of } 50 \mathrm{mM} \\
\text { Tris- } \mathrm{HCl}, 150 \mathrm{mM} \mathrm{NaCl}, 10 \% \text { glycerol, } \\
1 \% \text { glycine, } \mathrm{pH} 8\end{array}$ & [35] \\
\hline SV40 & Sf9 & $\begin{array}{l}\text { DNA plasmid } \\
\text { (up to } 17.7 \mathrm{~kb} \text { ) } \\
\text { Interaction between } \\
\text { capsid protein } \\
\text { and dsDNA }\end{array}$ & - & $\begin{array}{l}\text { VLP disassembly in the presence of } \\
\text { DTT, EDTA, EGTA/ Reassembly and } \\
\text { DNA packaging in the buffer } \\
\text { containing } \mathrm{MgCl}_{2}, \mathrm{CaCl}_{2} \text { (ATP) }\end{array}$ & {$[41,146,147]$} \\
\hline
\end{tabular}


Table 2. Cont.

\begin{tabular}{|c|c|c|c|c|c|}
\hline $\begin{array}{c}\text { VLP a } \\
\text { Platform }\end{array}$ & $\begin{array}{l}\text { Expression } \\
\text { System }\end{array}$ & $\begin{array}{c}\text { Cargo and } \\
\text { Loading Method }\end{array}$ & Targeting & Assembly Method & Ref. \\
\hline JC virus & Yeast & RNAi & IL 10 & 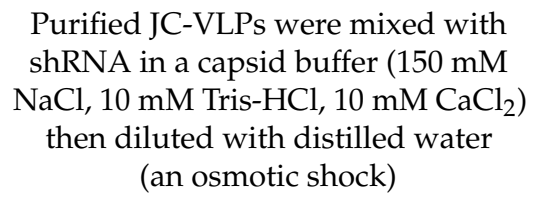 & [148] \\
\hline HPV & $\begin{array}{l}\text { Sf21/ } \\
\text { HEK } \\
293 \text { cell }\end{array}$ & $\begin{array}{l}\text { DNA plasmid } \\
\text { (up to } 8 \mathrm{~kb} \text { ) } \\
\text { Interaction between } \\
\text { capsid protein } \\
\text { and dsDNA }\end{array}$ & - & $\begin{array}{l}\text { VLP disassembly in the presence of } \\
\text { DTT (EGTA)/ Reassembly and DNA } \\
\text { packaging in the buffer containing } \\
\qquad \mathrm{CaCl}_{2},(\mathrm{ATP})\end{array}$ & [37-39] \\
\hline CCMV & Plant & $\begin{array}{l}\text { ssDNA, dsDNA } \\
\text { Electrostatic interaction } \\
\text { to capsid protein }\end{array}$ & - & $\begin{array}{l}\text { VLP disassembly in } 5 \times \text { assembly } \\
\text { buffer }(250 \mathrm{mM} \text { Tris- } \mathrm{HCl} \text { containing } \\
250 \mathrm{mM} \mathrm{NaCl}, 50 \mathrm{mM} \mathrm{KCl}, 25 \mathrm{mM} \\
\left.\mathrm{MgCl}_{2}, \mathrm{pH} 7.2\right) / \text { Reassembly and } \\
\text { DNA packaging by adding the } \\
\text { mixture of capsid protein and DNA } \\
\text { to } 1 \times \text { assembly buffer }\end{array}$ & [54] \\
\hline CCMV & $\begin{array}{l}\text { Plant/ } \\
\text { E. coli }\end{array}$ & $\begin{array}{c}\text { siRNA, mRNA, } \\
\text { Enzyme (HRP) } \\
\text { Electrostatic interaction } \\
\text { to capsid protein }\end{array}$ & $\begin{array}{l}\text { FOXA1 using } \\
\text { siRNA }\end{array}$ & $\begin{array}{l}\text { VLP disassembly in the high salt } \\
\text { concentration, neutral } \mathrm{pH} \\
\text { buffer/ Reassembly and cargoes } \\
\text { packaging by dialyzing to the first } \\
\text { assembly buffer ( } 50 \mathrm{mM} \text { Tris pH 7.2, } \\
50 \mathrm{mM} \mathrm{NaCl} 10 \mathrm{mM} \mathrm{KCl}, 5 \mathrm{mM} \\
\left.\mathrm{MgCl}_{2}, 1 \mathrm{mM} \mathrm{DTT}\right) \text {, then the second } \\
\text { buffer }\left(50 \mathrm{mM} \mathrm{NaCH}_{3} \mathrm{COO}, 8 \mathrm{mM}\right. \\
\left.\quad \mathrm{Mg}\left(\mathrm{CH}_{3} \mathrm{COO}\right)_{2}, \mathrm{pH} 4.5\right)\end{array}$ & [31-33] \\
\hline CMV & Plant & $\begin{array}{c}\text { DNA, protein, } \\
\text { fluorophore } \\
\text { Electrostatic interaction } \\
\text { with capsid protein }\end{array}$ & - & $\begin{array}{l}\text { VLP disassembly by } \\
\mathrm{LiCl} / \text { Reassembly and packaging by } \\
\text { dialyzing against an assembly buffer } \\
(20 \mathrm{mM} \text { Tris- } \mathrm{HCl}, 80 \mathrm{mM} \mathrm{KCl} 1 \mathrm{mM} \\
\left.\text { DTT, } 1 \mathrm{mM} \mathrm{MgCl}_{2}, \mathrm{pH} 7.2\right)\end{array}$ & [149] \\
\hline CCMV & E. coli & $\begin{array}{l}\text { DOX } \\
\text { Conjugated to } \\
\text { capsid proteins }\end{array}$ & $\begin{array}{l}\text { Cancer cells using } \\
\text { folic acid }\end{array}$ & $\begin{array}{l}\text { Purified proteins were dialyzed to the } \\
\text { buffer of } 0.1 \mathrm{M} \mathrm{NaCH}_{3} \mathrm{COO} \\
0.1 \mathrm{M} \mathrm{NaCl}, \mathrm{pH} 4.8\end{array}$ & [150] \\
\hline $\mathrm{MPyV}$ & E. coli & $\begin{array}{l}\text { GFP, m-Ruby3 protein } \\
\text { Genetic fusion to } \\
\text { capsid protein }\end{array}$ & - & $\begin{array}{c}\text { Purified proteins-linked capsomeres } \\
\text { were dialyzed to } 20 \mathrm{mM} \text { Tris, } \\
0.5 \mathrm{M}\left(\mathrm{NH}_{4}\right)_{2} \mathrm{SO}_{4}, 1 \mathrm{mM} \mathrm{CaCl} \\
5 \% \text { glycerol buffer }\end{array}$ & [75] \\
\hline RV & E. coli & $\begin{array}{l}\text { DOX } \\
\text { Conjugated to } \\
\text { capsid protein }\end{array}$ & $\begin{array}{l}\text { Hepatoma cells } \\
\text { using } \\
\text { lactobionic acid }\end{array}$ & $\begin{array}{l}\text { Purified, denatured capsid proteins } \\
\text { (in urea) were dialyzed to } \\
\mathrm{CH}_{3} \mathrm{COOH} / \mathrm{CH}_{3} \mathrm{COONa} \text { buffer } \\
\text { at } \mathrm{pH} 4.5\end{array}$ & [21] \\
\hline SV40 & Sf9 & $\begin{array}{l}\text { Magnetic nano-particles } \\
\text { (MNPs) } \\
\text { Electrostatic interaction } \\
\text { between capsid protein } \\
\text { and MNPs }\end{array}$ & EGF receptor & $\begin{array}{l}\text { VP1 capsid proteins of SV40 were } \\
\text { produced in Sf9 cells, pentamers were } \\
\text { purified and assembled around } \\
\text { magnetic nano-particles in MOPS } \\
\text { buffer ( } 20 \mathrm{mM} \text { MOPS-NaOH, } \\
150 \mathrm{mM} \mathrm{NaCl}, 2 \mathrm{mM} \mathrm{CaCl}, \mathrm{pH} 7.0)\end{array}$ & [151] \\
\hline SV40 & E. coli & $\begin{array}{l}\text { Quantum dots (QDs) } \\
\text { Direct association } \\
\text { between His-tag in VP1 } \\
\text { protein and } \mathrm{Zn}^{2+} \text { on the } \\
\text { QDs surface }\end{array}$ & - & $\begin{array}{l}\text { VP1 capsid proteins with a His-tag } \\
\text { were produced in E. coli, purified VP1 } \\
\text { pentamers and QDs were mixed and } \\
\text { dialyzed against an assembly buffer } \\
(10 \mathrm{mM} \text { Tris- } \mathrm{HCl}, 1 \mathrm{mM} \mathrm{CaCl} \\
250 \mathrm{mM} \mathrm{NaCl}, 5 \% \text { glycerol, } \mathrm{pH} 7.2)\end{array}$ & [152] \\
\hline
\end{tabular}


Table 2. Cont.

\begin{tabular}{|c|c|c|c|c|c|}
\hline $\begin{array}{c}\text { VLP a } \\
\text { Platform }\end{array}$ & $\begin{array}{l}\text { Expression } \\
\text { System }\end{array}$ & $\begin{array}{c}\text { Cargo and } \\
\text { Loading Method }\end{array}$ & Targeting & Assembly Method & Ref. \\
\hline BMV & Plant & $\begin{array}{l}\text { Gold nanoparticles } \\
\text { Electrostatic interaction } \\
\text { with capsid protein }\end{array}$ & - & $\begin{array}{c}\text { Purified BMV proteins and gold } \\
\text { particles were mixed in TKM buffer } \\
(10 \mathrm{mM} \text { Tris- } \mathrm{HCl}, 1 \mathrm{M} \mathrm{KCl}, 5 \mathrm{mM} \\
\mathrm{MgCl}_{2}, \mathrm{pH} 7.4 \text { and dialyzed against } \\
\text { an assembly buffer ( } 50 \mathrm{mM} \text { Tris- } \mathrm{HCl} \text {, } \\
50 \mathrm{mM} \mathrm{NaCl}, 10 \mathrm{mM} \mathrm{KCl}, 5 \mathrm{mM} \\
\left.\mathrm{MgCl}_{2}, \mathrm{pH} 7.4\right) \text {, then against SAMA } \\
\text { buffer }(50 \mathrm{mM} \text { NaOAc, } 8 \mathrm{mM} \\
\left.\mathrm{Mg}(\mathrm{OAc})_{2}, \mathrm{pH} 4.5\right)\end{array}$ & [153] \\
\hline RRV & E. coli & $\begin{array}{l}\text { Gold nanoparticles } \\
\text { Electrostatic interaction } \\
\text { with capsid protein }\end{array}$ & - & $\begin{array}{l}\text { Purified capsid proteins and } \\
\text { functionalized GNPs were mixed and } \\
\text { dialyzed against an assembly buffer } \\
(20 \mathrm{mM} \text { Tris- } \mathrm{HCl}, 50 \mathrm{mM} \mathrm{NaCl} \\
\left.10 \mathrm{mM} \mathrm{KCl}, 5 \mathrm{mM} \mathrm{MgCl}_{2}, \mathrm{pH} 7.4\right)\end{array}$ & [154] \\
\hline
\end{tabular}

a BMV: Brome mosaic virus; CCMV: Cowpea chlorotic mottle virus; CMV: cucumber mosaic virus; HBc: Hepatitis B core; JC: John Cunningham virus/human polyomavirus 2; MPyV: Murine polyomavirus; MS2: Bacteriophage MS2; P22: Bacteriophage P22; Q $\beta$ : Bacteriophage Qß; RRV: Ross River virus; RV: Rotavirus; SV40: Simian virus 40; DOX: doxycycline; EDTA: ethylenediaminetetraacetic acid.

During protein expression, some capsid proteins tend to assemble VLPs inside the hosts. To remove potential host-related impurities and encapsulate cargoes, the disassembly and reassembly of VLPs are needed. The use of bacteriophage MS2 VLPs in cargo delivery was reported by different groups. Generally, MS2 capsid proteins were produced and formed $27.5 \mathrm{~nm}$ MS2 VLPs in E. coli. The VLPs were subsequently purified and disassembled in glacial acetic acid. Since MS2 VLPs are able to reassemble and encapsulate negatively charged cargoes in vitro at neutral $\mathrm{pH}$, drugs, proteins or siRNA were loaded into the capsids for therapeutic delivery $[29,76,143]$. Targeting peptides were covalently linked to the capsid surfaces to specifically deliver the drugs to cells presenting the cognate receptor $[29,143]$. With a similar approach, Douglas et al. described a method to package a protein inside bacteriophage $\mathrm{P} 22$, which was performed by mixing of the cargo protein fused to a scaffold protein and bacteriophage P22 capsid proteins in a mild denaturing condition buffer $(1.5 \mathrm{M} \mathrm{GuHCl})$, followed by dialysis against a neutral buffer $[144,145]$. Another bacteriophage, $\mathrm{Q} \beta$ has been used to encapsidate a fluorescent protein [34]. Hepatitis B core protein $(\mathrm{HBc})$ VLPs were also exploited for drug delivery. The HBc VLPs assembled in E. coli, were denatured with urea, and reassembly and drug encapsulation was achieved by dialysis of the denatured proteins with a neutral buffer. The RGD peptide was genetically incorporated to HBc VLPs to target tumors [35]. In vitro VLPs were also explored in gene delivery. SV40 and HPV VLPs were produced in insect or mammalian cells. The particles were disassembled in the presence of reducing and chelating agents, DNA plasmids were then packaged inside the VLPs and delivered to target cells $[37-39,41,146,147]$. Human polyomavirus 2 (JC) VLPs produced in yeast have been used to deliver RNAi, which was loaded via an osmotic shock [148].

CCMV VLPs are widely tested for therapeutic delivery due to their $\mathrm{pH}$-dependent capsid assembly [155]. CCMV VLPs were produced in plant cells, the particles were then disassembled in a high-salt concentration buffer at neutral $\mathrm{pH}$. Reassembly and packaging followed by adding cargoes and dialyzing into an acidic buffer (at pH 4.5-4.8) [31-33], which can be used to package RNA replicons [156], or a neutral buffer which has been used with DNA cargoes [54]. CCMV VLPs were also produced using E. coli by expressing soluble capsid proteins, followed by purification and assembly in the presence of cargoes. To target subcutaneous cancers, folic acid (FA) was conjugated to CCMV capsid proteins [32,150]. Other VLPs obtained by in-vitro assembly were also tested for loading and drug delivery. Murine polyomavirus (MPyV) capsomeres fused to a desired protein were expressed in E. coli and the purified capsomeres were dialyzed resulting in the formation of VLPs 
containing the guest protein for delivery [75]. Zhao et al. described a method to deliver the chemotherapy drug doxorubicin (DOX) using rotavirus (RV). RV structural protein VP6 formed inclusion bodies during expression in E. coli, and the protein was then purified under denaturing condition (8 M urea). DOX was conjugated to denatured VP proteins and the assembly of VLPs occurred during protein dialysis into a low pH buffer [21].

For diagnostic purposes such as magnetic resonance imaging (MRI), magnetic nanoparticles can also be coated with capsid proteins and additionally endowed with a targeting function. VP1 ${ }^{\triangle \mathrm{C} 589}, \mathrm{VP} 1^{\mathrm{wt}}$ or $\mathrm{VP} 1^{\mathrm{N} 138 \mathrm{C}}$ of SV40 were produced in Sf9 cells and pentamers were purified and assembled around magnetic nano-particles in MOPS (3-Morpholinopropane1-sulfonic acid) buffer. The latter two particles were crosslinked with epidermal growth factor (EGF) for the targeting of EGFR expressing cells using heterobifunctional crosslinkers with N-hydoxysuccinimide and maleimide groups [151]. Similarly, SV40 VLPs produced in $E$. coli have been used to encapsulate quantum dots for imaging [152]. Brome mosaic virus (BMV) and Ross River virus (RRV) particles were also explored for medical imaging. The purified capsid proteins were mixed with functionalized gold nanoparticles (GNPs) and dialyzed against an assembly buffer. The encapsulation was regulated by the electrostatic interactions between capsid proteins and gold nanoparticles, followed by the capsid protein-capsid protein interactions $[153,154]$.

\section{Conclusions}

VLPs have been widely exploited for vaccine development and therapeutic delivery with success in the clinic and promising preclinical evaluations. In vitro VLP production technology has emerged as a versatile technology besides the in vivo method. The formation of VLPs under controllable and defined conditions enables the technology to create multi-vaccine candidates by combining different antigens within a particle while avoiding the unpredictable immune response related to possible host-related contaminations. In vitro assembly of VLPs also offers a feasible tool to control the packaging amount and cargo components for therapeutic delivery.

In vitro VLP assembly is a complex process and differs among viral capsids. Even though many in-vitro VLPs have been produced, it is still unclear whether all virus capsids are amenable to ex cella production. Many factors need to be optimized for each candidate to assemble VLPs in vitro, improve assembly yields, and enable large-scale production. Cell-free protein synthesis in combination with in vitro VLP assembly bears potential for the generation of various synthetic biology products at a smaller scale. In vitro VLPs have been widely used as VLP-based protein vaccines. When in vitro nucleic acid encapsidation becomes more accessible, in vitro VLPs might also become an efficient and safe technology for vector VLP vaccines, which deliver an antigen-coding sequence, or for gene therapy vectors for treating diseases. Also for other therapeutic delivery strategies, recent advances provided mostly a proof of concept. Further work is needed to fully tap the potential of in vitro VLPs, but the future looks bright.

Author Contributions: Conceptualization, D.T.L. and K.M.M.; writing—original draft preparation, D.T.L.; writing-review and editing, K.M.M.; All authors have read and agreed to the published version of the manuscript.

Funding: We acknowledge support for the publication costs by the Open Access Publication Fund of Bielefeld University. D.T.L. acknowledges support by DAAD (Deutscher Akademischer Austauschdienst) for providing a PhD fellowship (Personal ref. no.: 91651068).

Institutional Review Board Statement: Not applicable.

Informed Consent Statement: Not applicable.

Data Availability Statement: Not applicable.

Conflicts of Interest: The authors declare no conflict of interest. 


\section{References}

1. Lua, L.H.L.; Connors, N.K.; Sainsbury, F.; Chuan, Y.P.; Wibowo, N.; Middelberg, A.P.J. Bioengineering virus-like particles as vaccines. Biotechnol. Bioeng. 2014, 111, 425-440. [CrossRef] [PubMed]

2. Jeevanandam, J.; Barhoum, A.; Chan, Y.S.; Dufresne, A.; Danquah, M.K. Review on nanoparticles and nanostructured materials: History, sources, toxicity and regulations. Beilstein J. Nanotechnol. 2018, 9, 1050-1074. [CrossRef]

3. Qian, C.; Liu, X.; Xu, Q.; Wang, Z.; Chen, J.; Li, T.; Zheng, Q.; Yu, H.; Gu, Y.; Li, S.; et al. Recent Progress on the Versatility of Virus-Like Particles. Vaccines 2020, 8, 139. [CrossRef] [PubMed]

4. Rohovie, M.J.; Nagasawa, M.; Swartz, J.R. Virus-like particles: Next-generation nanoparticles for targeted therapeutic delivery. Bioeng. Transl. Med. 2017, 2, 43-57. [CrossRef] [PubMed]

5. Lee, S.Y.; Lim, J.S.; Harris, M.T. Synthesis and application of virus-based hybrid nanomaterials. Biotechnol. Bioeng. 2012, 109, 16-30. [CrossRef] [PubMed]

6. Mohsen, M.; Gomes, A.; Vogel, M.; Bachmann, M. Interaction of Viral Capsid-Derived Virus-Like Particles (VLPs) with the Innate Immune System. Vaccines 2018, 6, 37. [CrossRef] [PubMed]

7. Vicente, T.; Mota, J.P.B.; Peixoto, C.; Alves, P.M.; Carrondo, M.J.T. Rational design and optimization of downstream processes of virus particles for biopharmaceutical applications: Current advances. Biotechnol. Adv. 2011, 29, 869-878. [CrossRef]

8. Gu, Y.; Wei, M.; Wang, D.; Li, Z.; Xie, M.; Pan, H.; Wu, T.; Zhang, J.; Li, S.; Xia, N. Characterization of an Escherichia coli-derived human papillomavirus type 16 and 18 bivalent vaccine. Vaccine 2017, 35, 4637-4645. [CrossRef] [PubMed]

9. Wei, M.; Wang, D.; Li, Z.; Song, S.; Kong, X.; Mo, X.; Yang, Y.; He, M.; Li, Z.; Huang, B.; et al. N-terminal truncations on L1 proteins of human papillomaviruses promote their soluble expression in Escherichia coli and self-assembly in vitro. Emerg. Microbes Infect. 2018, 7, 1-12. [CrossRef]

10. Zeltins, A. Construction and characterization of virus-like particles: A review. Mol. Biotechnol. 2013, 53, 92-107. [CrossRef]

11. Roldão, A.; Mellado, M.C.M.; Castilho, L.R.; Carrondo, M.J.T.; Alves, P.M. Virus-like particles in vaccine development. Expert Rev. Vaccines 2010, 9, 1149-1176. [CrossRef] [PubMed]

12. Huang, X.; Wang, X.; Zhang, J.; Xia, N.; Zhao, Q. Escherichia coli-derived virus-like particles in vaccine development. npj Vaccines 2017, 2, 3. [CrossRef] [PubMed]

13. Ladd Effio, C.; Baumann, P.; Weigel, C.; Vormittag, P.; Middelberg, A.; Hubbuch, J. High-throughput process development of an alternative platform for the production of virus-like particles in Escherichia coli. J. Biotechnol. 2016, 219, 7-19. [CrossRef]

14. Bajaj, S.; Banerjee, M. In vitro assembly of polymorphic virus-like particles from the capsid protein of a nodavirus. Virology 2016, 496, 106-115. [CrossRef] [PubMed]

15. Xu, J.; Guo, H.-C.C.; Wei, Y.-Q.Q.; Dong, H.; Han, S.-C.C.; Ao, D.; Sun, D.-H.H.; Wang, H.-M.M.; Cao, S.-Z.Z.; Sun, S.-Q.Q.; et al. Self-assembly of virus-like particles of canine parvovirus capsid protein expressed from Escherichia coli and application as virus-like particle vaccine. Appl. Microbiol. Biotechnol. 2014, 98, 3529-3538. [CrossRef] [PubMed]

16. Guo, H.; Zhu, J.; Tan, Y.; Li, C.; Chen, Z.; Sun, S.; Liu, G. Self-assembly of virus-like particles of rabbit hemorrhagic disease virus capsid protein expressed in Escherichia coli and their immunogenicity in rabbits. Antiviral Res. 2016, 131, 85-91. [CrossRef]

17. Yazdani, R.; Shams-Bakhsh, M.; Hassani-Mehraban, A.; Arab, S.S.; Thelen, N.; Thiry, M.; Crommen, J.; Fillet, M.; Jacobs, N.; Brans, A.; et al. Production and characterization of virus-like particles of grapevine fanleaf virus presenting L2 epitope of human papillomavirus minor capsid protein. BMC Biotechnol. 2019, 19, 81. [CrossRef]

18. Sánchez-Rodríguez, S.P.; Münch-Anguiano, L.; Echeverría, O.; Vázquez-Nin, G.; Mora-Pale, M.; Dordick, J.S.; Bustos-Jaimes, I. Human parvovirus B19 virus-like particles: In vitro assembly and stability. Biochimie 2012, 94, 870-878. [CrossRef]

19. Le, D.T.; Radukic, M.T.; Müller, K.M. Adeno-associated virus capsid protein expression in Escherichia coli and chemically defined capsid assembly. Sci. Rep. 2019, 9, 19631. [CrossRef]

20. Bin Mohamed Suffian, I.F.; Garcia-Maya, M.; Brown, P.; Bui, T.; Nishimura, Y.; Palermo, A.R.B.M.J.; Ogino, C.; Kondo, A.; Al-Jamal, K.T. Yield Optimisation of Hepatitis B Virus Core Particles in E. coli Expression System for Drug Delivery Applications. Sci. Rep. 2017, 7, 43160. [CrossRef]

21. Zhang, L.; Zhang, J.; Zhang, Z.; Chen, Y.; Zhao, Q.; Chen, W. Self-Assembled Virus-Like Particles from Rotavirus Structural Protein VP6 for Targeted Drug Delivery. Bioconjug. Chem. 2011, 22, 346-352. [CrossRef]

22. Steinbach, S.; Wistuba, A.; Bock, T.; Kleinschmidt, J.A. Assembly of adeno-associated virus type 2 capsids in vitro. J. Gen. Virol. 1997, 78, 1453-1462. [CrossRef] [PubMed]

23. Smith, G.; Raghunandan, R.; Wu, Y.; Liu, Y.; Massare, M.; Nathan, M.; Zhou, B.; Lu, H.; Boddapati, S.; Li, J.; et al. Respiratory Syncytial Virus Fusion Glycoprotein Expressed in Insect Cells Form Protein Nanoparticles That Induce Protective Immunity in Cotton Rats. PLoS ONE 2012, 7, e50852. [CrossRef]

24. Acosta-Rivero, N.; Rodriguez, A.; Musacchio, A.; Falcón, V.; Suarez, V.M.; Martinez, G.; Guerra, I.; Paz-Lago, D.; Morera, Y.; De La Rosa, M.C.; et al. In vitro assembly into virus-like particles is an intrinsic quality of Pichia pastoris derived HCV core protein. Biochem. Biophys. Res. Commun. 2004, 325, 68-74. [CrossRef] [PubMed]

25. Tinafar, A.; Jaenes, K.; Pardee, K. Synthetic Biology Goes Cell-Free. BMC Biol. 2019, 17, 64. [CrossRef]

26. Bundy, B.C.; Swartz, J.R. Efficient disulfide bond formation in virus-like particles. J. Biotechnol. 2011, 154, 230-239. [CrossRef]

27. Bundy, B.C.; Franciszkowicz, M.J.; Swartz, J.R. Escherichia coli-based cell-free synthesis of virus-like particles. Biotechnol. Bioeng. 2008, 100, 28-37. [CrossRef] 
28. Spice, A.J.; Aw, R.; Bracewell, D.G.; Polizzi, K.M. Synthesis and Assembly of Hepatitis B Virus-Like Particles in a Pichia pastoris Cell-Free System. Front. Bioeng. Biotechnol. 2020, 8, 72. [CrossRef]

29. Ashley, C.E.; Carnes, E.C.; Phillips, G.K.; Durfee, P.N.; Buley, M.D.; Lino, C.A.; Padilla, D.P.; Phillips, B.; Carter, M.B.; Willman, C.L.; et al. Cell-specific delivery of diverse cargos by bacteriophage MS2 virus-like particles. ACS Nano 2011, 5, 5729-5745. [CrossRef] [PubMed]

30. McCarthy, M.P.; White, W.I.; Palmer-Hill, F.; Koenig, S.; Suzich, J.A. Quantitative Disassembly and Reassembly of Human Papillomavirus Type 11 Virus like Particles In Vitro. J. Virol. 1998, 72, 32-41. [CrossRef]

31. Villagrana-Escareño, M.V.; Reynaga-Hernández, E.; Galicia-Cruz, O.G.; Durán-Meza, A.L.; De la Cruz-González, V.; HernándezCarballo, C.Y.; Ruíz-García, J. VLPs Derived from the CCMV Plant Virus Can Directly Transfect and Deliver Heterologous Genes for Translation into Mammalian Cells. Biomed Res. Int. 2019, 2019, 4630891. [CrossRef] [PubMed]

32. Lam, P.; Steinmetz, N.F. Delivery of siRNA therapeutics using cowpea chlorotic mottle virus-like particles. Biomater. Sci. 2019, 7, 3138-3142. [CrossRef] [PubMed]

33. Comellas-Aragonès, M.; Engelkamp, H.; Claessen, V.I.; Sommerdijk, N.A.J.M.; Rowan, A.E.; Christianen, P.C.M.; Maan, J.C.; Verduin, B.J.M.; Cornelissen, J.J.L.M.; Nolte, R.J.M. A virus-based single-enzyme nanoreactor. Nat. Nanotechnol. 2007, 2, 635-639. [CrossRef]

34. Fang, P.Y.; Ramos, L.M.G.; Holguin, S.Y.; Hsiao, C.; Bowman, J.C.; Yang, H.W.; Williams, L.D. Functional RNAs: Combined assembly and packaging in VLPs. Nucleic Acids Res. 2016, 45, 3519-3527. [CrossRef]

35. Ren, L.; Zhang, X.; Bi, S.; Shan, W.; Ye, S.; Hu, B.; Wu, Y.; Lv, X.; Zhang, D.; Zhou, X. Modularized peptides modified HBc virus-like particles for encapsulation and tumor-targeted delivery of doxorubicin. Nanomedicine Nanotechnology, Biol. Med. 2017, 14, 725-734. [CrossRef]

36. Lee, E.B.; Kim, J.-H.; Hur, W.; Choi, J.E.; Kim, S.M.; Park, D.J.; Kang, B.-Y.; Lee, G.W.; Yoon, S.K. Liver-specific Gene Delivery Using Engineered Virus-Like Particles of Hepatitis E Virus. Sci. Rep. 2019, 9, 1616. [CrossRef]

37. Cerqueira, C.; Pang, Y.-Y.S.; Day, P.M.; Thompson, C.D.; Buck, C.B.; Lowy, D.R.; Schiller, J.T. A Cell-Free Assembly System for Generating Infectious Human Papillomavirus 16 Capsids Implicates a Size Discrimination Mechanism for Preferential Viral Genome Packaging. J. Virol. 2016, 90, 1096-1107. [CrossRef]

38. Cerqueira, C.; Thompson, C.D.; Day, P.M.; Pang, Y.-Y.S.; Lowy, D.R.; Schiller, J.T. Efficient Production of Papillomavirus Gene Delivery Vectors in Defined In Vitro Reactions. Mol. Ther.-Methods Clin. Dev. 2017, 5, 165-179. [CrossRef] [PubMed]

39. Touze, A.; Coursaget, P. In vitro gene transfer using human papillomavirus-like particles. Nucleic Acids Res. 1998, 26, 1317-1323. [CrossRef]

40. Colomar, M.C.; Degoumois-Sahli, C.; Beard, P. Opening and refolding of simian virus 40 and in vitro packaging of foreign DNA. J. Virol. 1993, 67, 2779-2786. [CrossRef] [PubMed]

41. Sandalon, Z.; Dalyot-Herman, N.; Oppenheim, A.B.; Oppenheim, A. In Vitro Assembly of SV40 Virions and Pseudovirions: Vector Development for Gene Therapy. Hum. Gene Ther. 1997, 8, 843-849. [CrossRef]

42. Perlmutter, J.D.; Hagan, M.F. Mechanisms of virus assembly. Annu. Rev. Phys. Chem. 2015, 66, 217-239. [CrossRef]

43. Hagan, M.F. Modeling Viral Capsid Assembly. In Advances in Chemical Physics; Rice, S.A., Dinner, A.R., Eds.; John Wiley \& Sons, Inc.: Hoboken, NJ, USA, 2014; pp. 1-68. ISBN 6176321972.

44. Hagan, M.F.; Elrad, O.M. Understanding the Concentration Dependence of Viral Capsid Assembly Kinetics-The Origin of the Lag Time and Identifying the Critical Nucleus Size. Biophys. J. 2010, 98, 1065-1074. [CrossRef]

45. Chi, E.Y.; Krishnan, S.; Randolph, T.W.; Carpenter, J.F. Physical stability of proteins in aqueous solution: Mechanism and driving forces in nonnative protein aggregation. Pharm. Res. 2003, 20, 1325-1336. [CrossRef]

46. Barklis, E.; Alfadhli, A.; McQuaw, C.; Yalamuri, S.; Still, A.; Barklis, R.L.; Kukull, B.; López, C.S. Characterization of the In Vitro HIV-1 Capsid Assembly Pathway. J. Mol. Biol. 2009, 387, 376-389. [CrossRef]

47. Johnson, J.M.; Tang, J.; Nyame, Y.; Willits, D.; Young, M.J.; Zlotnick, A. Regulating self-assembly of spherical oligomers. Nano Lett. 2005, 5, 765-770. [CrossRef] [PubMed]

48. Dominy, B.N.; Perl, D.; Schmid, F.X.; Brooks, C.L. The effects of ionic strength on protein stability: The cold shock protein family. J. Mol. Biol. 2002, 319, 541-554. [CrossRef]

49. Lavelle, L.; Gingery, M.; Phillips, M.; Gelbart, W.M.; Knobler, C.M.; Cadena-Nava, R.D.; Vega-Acosta, J.R.; Pinedo-Torres, L.A.; Ruiz-Garcia, J. Phase diagram of self-assembled viral capsid protein polymorphs. J. Phys. Chem. B 2009, 113, 3813-3819. [CrossRef]

50. Jaballah, S.A.; Bailey, G.D.; Desfosses, A.; Hyun, J.; Mitra, A.K.; Kingston, R.L. In vitro assembly of the Rous Sarcoma Virus capsid protein into hexamer tubes at physiological temperature. Sci. Rep. 2017, 7, 2913. [CrossRef] [PubMed]

51. Uetrecht, C.; Watts, N.R.; Stahl, S.J.; Wingfield, P.T.; Steven, A.C.; Heck, A.J.R. Subunit exchange rates in Hepatitis B virus capsids are geometry- and temperature-dependent. Phys. Chem. Chem. Phys. 2010, 12, 13368-13371. [CrossRef]

52. Comas-Garcia, M.; Knobler, C.M.; Gelbart, W.M.; Gopal, A.; Garmann, R.F. The Assembly Pathway of an Icosahedral SingleStranded RNA Virus Depends on the Strength of Inter-Subunit Attractions. J. Mol. Biol. 2013, 426, 1050-1060. [CrossRef]

53. Gelbart, W.M.; Garmann, R.F.; Cadena-Nava, R.D.; Comas-Garcia, M.; Knobler, C.M.; Rao, A.L.N. Self-Assembly of Viral Capsid Protein and RNA Molecules of Different Sizes: Requirement for a Specific High Protein/RNA Mass Ratio. J. Virol. 2011, 86, 3318-3326. [CrossRef] 
54. de Ruiter, M.V.; van der Hee, R.M.; Driessen, A.J.M.; Keurhorst, E.D.; Hamid, M.; Cornelissen, J.J.L.M. Polymorphic assembly of virus-capsid proteins around DNA and the cellular uptake of the resulting particles. J. Control. Release 2019, 307, 342-354. [CrossRef]

55. Comas-Garcia, M.; Kroupa, T.; Datta, S.A.K.; Harvin, D.P.; Hu, W.-S.; Rein, A. Efficient support of virus-like particle assembly by the HIV-1 packaging signal. Elife 2018, 7, e38438. [CrossRef] [PubMed]

56. Kunkel, M.; Lorinczi, M.; Rijnbrand, R.; Lemon, S.M.; Watowich, S.J. Self-Assembly of Nucleocapsid-Like Particles from Recombinant Hepatitis C Virus Core Protein. J. Virol. 2001, 75, 2119-2129. [CrossRef] [PubMed]

57. Sarker, S.; Terrón, M.C.; Khandokar, Y.; Aragão, D.; Hardy, J.M.; Radjainia, M.; Jiménez-Zaragoza, M.; de Pablo, P.J.; Coulibaly, F.; Luque, D.; et al. Structural insights into the assembly and regulation of distinct viral capsid complexes. Nat. Commun. 2016, 7, 13014. [CrossRef]

58. van Rosmalen, M.G.M.; Kamsma, D.; Biebricher, A.S.; Li, C.; Zlotnick, A.; Roos, W.H.; Wuite, G.J.L. Revealing in real-time a multistep assembly mechanism for SV40 virus-like particles. Sci. Adv. 2020, 6, eaaz1639. [CrossRef] [PubMed]

59. Medina, E.M.; Andrews, B.T.; Nakatani, E.; Catalano, C.E. The bacteriophage lambda gpNu3 scaffolding protein is an intrinsically disordered and biologically functional procapsid assembly catalyst. J. Mol. Biol. 2011, 412, 723-736. [CrossRef]

60. Motwani, T.; Lokareddy, R.K.; Dunbar, C.A.; Cortines, J.R.; Jarrold, M.F.; Cingolani, G.; Teschke, C.M. A viral scaffolding protein triggers portal ring oligomerization and incorporation during procapsid assembly. Sci. Adv. 2017, 3, e1700423. [CrossRef] [PubMed]

61. Wang, S.; Palasingam, P.; Nøkling, R.H.; Lindqvist, B.H.; Dokland, T. In vitro assembly of bacteriophage P4 procapsids from purified capsid and scaffolding proteins. Virology 2000, 275, 133-144. [CrossRef] [PubMed]

62. Cerritelli, M.E.; Studier, F.W. Assembly of T7 capsids from independently expressed and purified head protein and scaffolding protein. J. Mol. Biol. 1996, 258, 286-298. [CrossRef]

63. Fu, C.; Morais, M.C.; Battisti, A.J.; Rossmann, M.G.; Prevelige, P.E. Molecular Dissection of Ø29 Scaffolding Protein Function in an in Vitro Assembly System. J. Mol. Biol. 2007, 366, 1161-1173. [CrossRef] [PubMed]

64. Newcomb, W.W.; Homa, F.L.; Thomsen, D.R.; Brown, J.C. In vitro assembly of the herpes simplex virus procapsid: Formation of small procapsids at reduced scaffolding protein concentration. J. Struct. Biol. 2001, 133, 23-31. [CrossRef] [PubMed]

65. Sánchez-Rodríguez, S.P.; Morán-García, A. del C.; Bolonduro, O.; Dordick, J.S.; Bustos-Jaimes, I. Enhanced assembly and colloidal stabilization of primate erythroparvovirus 1 virus-like particles for improved surface engineering. Acta Biomater. 2016, 35, 206-214. [CrossRef]

66. Lampel, A.; Bram, Y.; Levy-Sakin, M.; Bacharach, E.; Gazit, E. The Effect of Chemical Chaperones on the Assembly and Stability of HIV-1 Capsid Protein. PLoS ONE 2013, 8, 25-29. [CrossRef] [PubMed]

67. Sinn, S.; Yang, L.; Biedermann, F.; Wang, D.; Kübel, C.; Cornelissen, J.J.L.M.; De Cola, L. Templated Formation of Luminescent Virus-like Particles by Tailor-Made Pt(II) Amphiphiles. J. Am. Chem. Soc. 2018, 140, 2355-2362. [CrossRef] [PubMed]

68. Millán, J.G.; Brasch, M.; Anaya-Plaza, E.; De La Escosura, A.; Velders, A.H.; Reinhoudt, D.N.; Torres, T.; Koay, M.S.T.; Cornelissen, J.J.L.M. Self-assembly triggered by self-assembly: Optically active, paramagnetic micelles encapsulated in protein cage nanoparticles. J. Inorg. Biochem. 2014, 136, 140-146. [CrossRef] [PubMed]

69. Kwak, M.; Minten, I.J.; Anaya, D.M.; Musser, A.J.; Brasch, M.; Nolte, R.J.M.; Müllen, K.; Cornelissen, J.J.L.M.; Herrmann, A. Virus-like particles templated by DNA micelles: A general method for loading virus nanocarriers. J. Am. Chem. Soc. 2010, 132, 7834-7835. [CrossRef] [PubMed]

70. Comellas-Aragonès, M.; de la Escosura, A.; Dirks, A.T.J.; van der Ham, A.; Fustè-Cuñè, A.; Cornelissen, J.J.L.M.; Nolte, R.J.M. Controlled Integration of Polymers into Viral Capsids. Biomacromolecules 2009, 10, 3141-3147. [CrossRef]

71. Sikkema, F.D.; Comellas-Aragonès, M.; Fokkink, R.G.; Verduin, B.J.M.; Cornelissen, J.J.L.M.; Nolte, R.J.M. Monodisperse polymer-virus hybrid nanoparticles. Org. Biomol. Chem. 2007, 5, 54-57. [CrossRef]

72. Mach, H.; Middaugh, C.R.; Lewis, R.V. Statistical determination of the average values of the extinction coefficients of tryptophan and tyrosine in native proteins. Anal. Biochem. 1992, 200, 74-80. [CrossRef]

73. Mach, H.; Middaugh, C.R. Simultaneous Monitoring of the Environment of Tryptophan, Tyrosine, and Phenylalanine Residues in Proteins by Near-Ultraviolet Second-Derivative Spectroscopy. Anal. Biochem. 1994, 222, 323-331. [CrossRef] [PubMed]

74. Walker, J.M. The Bicinchoninic Acid (BCA) Assay for Protein Quantitation. Methods Mol. Biol. 1994, 32, 5-8. [CrossRef]

75. Dashti, N.H.; Abidin, R.S.; Sainsbury, F. Programmable in Vitro Coencapsidation of Guest Proteins for Intracellular Delivery by Virus-like Particles. ACS Nano 2018, 12, 4615-4623. [CrossRef] [PubMed]

76. Glasgow, J.E.; Capehart, S.L.; Francis, M.B.; Tullman-Ercek, D. Osmolyte-mediated encapsulation of proteins inside MS2 viral capsids. ACS Nano 2012, 6, 8658-8664. [CrossRef] [PubMed]

77. Termini, E.; Description, F.P.; Street, D.; Id, B.S.; Schedule, E.; Code, F.F.; Funds, F.; Code, S.F.; Funds, S.; Funds, L.; et al. SARS-CoV-2 spike glycoprotein vaccine candidate NVX-CoV2373 elicits immunogenicity in baboons and protection in mice. bioRxiv 2020. [CrossRef]

78. Zhang, X.; Wei, M.; Pan, H.; Lin, Z.; Wang, K.; Weng, Z.; Zhu, Y.; Xin, L.; Zhang, J.; Li, S.; et al. Robust manufacturing and comprehensive characterization of recombinant hepatitis E virus-like particles in Hecolin ${ }^{\circledR}$. Vaccine 2014, 32, 4039-4050. [CrossRef] [PubMed]

79. European Medicines Agency Gardasil: EPAR—Scientific discussion. Available online: https://www.ema.europa.eu/en/ documents/scientific-discussion/gardasil-epar-scientific-discussion_en.pdf (accessed on 20 December 2020). 
80. Zhao, Q.; Allen, M.J.; Wang, Y.; Wang, B.; Wang, N.; Shi, L.; Sitrin, R.D. Disassembly and reassembly improves morphology and thermal stability of human papillomavirus type 16 virus-like particles. Nanomed. Nanotechnol. Biol. Med. 2012, 8, 1182-1189. [CrossRef]

81. Valbuena, A.; Maity, S.; Mateu, M.G.; Roos, W.H. Visualization of Single Molecules Building a Viral Capsid Protein Lattice through Stochastic Pathways. ACS Nano 2020, 14, 8724-8734. [CrossRef]

82. Ashcroft, A.E. Mass spectrometry-based studies of virus assembly. Curr. Opin. Virol. 2019, 36, 17-24. [CrossRef]

83. Prevelige, P.E.; Thomas, D.; King, J. Nucleation and growth phases in the polymerization of coat and scaffolding subunits into icosahedral procapsid shells. Biophys. J. 1993, 64, 824-835. [CrossRef]

84. Li, C.; Kneller, A.R.; Jacobson, S.C.; Zlotnick, A. Single Particle Observation of SV40 VP1 Polyanion-Induced Assembly Shows That Substrate Size and Structure Modulate Capsid Geometry. ACS Chem. Biol. 2017, 12, 1327-1334. [CrossRef] [PubMed]

85. Medrano, M.; Fuertes, M.Á.; Valbuena, A.; Carrillo, P.J.P.; Rodríguez-Huete, A.; Mateu, M.G. Imaging and Quantitation of a Succession of Transient Intermediates Reveal the Reversible Self-Assembly Pathway of a Simple Icosahedral Virus Capsid. J. Am. Chem. Soc. 2016, 138, 15385-15396. [CrossRef]

86. Ignatiou, A.; Brasilès, S.; El Sadek Fadel, M.; Bürger, J.; Mielke, T.; Topf, M.; Tavares, P.; Orlova, E.V. Structural transitions during the scaffolding-driven assembly of a viral capsid. Nat. Commun. 2019, 10, 4840. [CrossRef] [PubMed]

87. Khaykelson, D.; Raviv, U. Studying viruses using solution X-ray scattering. Biophys. Rev. 2020, 12, 41-48. [CrossRef] [PubMed]

88. Tuma, R.; Tsuruta, H.; French, K.H.; Prevelige, P.E. Detection of Intermediates and Kinetic Control during Assembly of Bacteriophage P22 Procapsid. J. Mol. Biol. 2008, 381, 1395-1406. [CrossRef] [PubMed]

89. Tresset, G.; Le Coeur, C.; Bryche, J.-F.; Tatou, M.; Zeghal, M.; Charpilienne, A.; Poncet, D.; Constantin, D.; Bressanelli, S. Norovirus Capsid Proteins Self-Assemble through Biphasic Kinetics via Long-Lived Stave-like Intermediates. J. Am. Chem. Soc. 2013, 135, 15373-15381. [CrossRef] [PubMed]

90. Asor, R.; Selzer, L.; Schlicksup, C.J.; Zhao, Z.; Zlotnick, A.; Raviv, U. Assembly Reactions of Hepatitis B Capsid Protein into Capsid Nanoparticles Follow a Narrow Path through a Complex Reaction Landscape. ACS Nano 2019, 13, 7610-7626. [CrossRef]

91. Chevreuil, M.; Law-Hine, D.; Chen, J.; Bressanelli, S.; Combet, S.; Constantin, D.; Degrouard, J.; Möller, J.; Zeghal, M.; Tresset, G. Nonequilibrium self-assembly dynamics of icosahedral viral capsids packaging genome or polyelectrolyte. Nat. Commun. 2018, 9, 3071. [CrossRef] [PubMed]

92. Panahandeh, S.; Li, S.; Marichal, L.; Leite Rubim, R.; Tresset, G.; Zandi, R. How a Virus Circumvents Energy Barriers to Form Symmetric Shells. ACS Nano 2020, 14, 3170-3180. [CrossRef] [PubMed]

93. Uetrecht, C.; Barbu, I.M.; Shoemaker, G.K.; van Duijn, E.; Heck, A.J.R. Interrogating viral capsid assembly with ion mobility-mass spectrometry. Nat. Chem. 2011, 3, 126-132. [CrossRef] [PubMed]

94. Lutomski, C.A.; Lyktey, N.A.; Pierson, E.E.; Zhao, Z.; Zlotnick, A.; Jarrold, M.F. Multiple Pathways in Capsid Assembly. J. Am. Chem. Soc. 2018, 140, 5784-5790. [CrossRef] [PubMed]

95. Shoemaker, G.K.; van Duijn, E.; Crawford, S.E.; Uetrecht, C.; Baclayon, M.; Roos, W.H.; Wuite, G.J.L.; Estes, M.K.; Prasad, B.V.V.; Heck, A.J.R. Norwalk Virus Assembly and Stability Monitored by Mass Spectrometry. Mol. Cell. Proteomics 2010, 9, $1742-1751$. [CrossRef]

96. Harms, Z.D.; Selzer, L.; Zlotnick, A.; Jacobson, S.C. Monitoring Assembly of Virus Capsids with Nanofluidic Devices. ACS Nano 2015, 9, 9087-9096. [CrossRef]

97. Garmann, R.F.; Goldfain, A.M.; Manoharan, V.N. Measurements of the self-assembly kinetics of individual viral capsids around their RNA genome. Proc. Natl. Acad. Sci. 2019, 116, 22485-22490. [CrossRef]

98. Borodavka, A.; Tuma, R.; Stockley, P.G. Evidence that viral RNAs have evolved for efficient, two-stage packaging. Proc. Natl. Acad. Sci. USA 2012, 109, 15769-15774. [CrossRef]

99. Marchetti, M.; Kamsma, D.; Cazares Vargas, E.; Hernandez García, A.; van der Schoot, P.; de Vries, R.; Wuite, G.J.L.; Roos, W.H. Real-Time Assembly of Viruslike Nucleocapsids Elucidated at the Single-Particle Level. Nano Lett. 2019, 19, 5746-5753. [CrossRef]

100. Uchihashi, T.; Scheuring, S. Applications of high-speed atomic force microscopy to real-time visualization of dynamic biomolecular processes. Biochim. Biophys. Acta-Gen. Subj. 2018, 1862, 229-240. [CrossRef]

101. Jennings, G.T.; Bachmann, M.F. The coming of age of virus-like particle vaccines. Biol. Chem. 2008, 389, 521-536. [CrossRef]

102. Jegerlehner, A.; Storni, T.; Lipowsky, G.; Schmid, M.; Pumpens, P.; Bachmann, M.F. Regulation of IgG antibody responses by epitope density and CD21-mediated costimulation. Eur. J. Immunol. 2002, 32, 3305-3314. [CrossRef]

103. Chackerian, B.; Lenz, P.; Lowy, D.R.; Schiller, J.T. Determinants of Autoantibody Induction by Conjugated Papillomavirus Virus-Like Particles. J. Immunol. 2002, 169, 6120-6126. [CrossRef]

104. Zabel, F.; Mohanan, D.; Bessa, J.; Link, A.; Fettelschoss, A.; Saudan, P.; Kündig, T.M.; Bachmann, M.F. Viral Particles Drive Rapid Differentiation of Memory B Cells into Secondary Plasma Cells Producing Increased Levels of Antibodies. J. Immunol. 2014, 192, 5499-5508. [CrossRef] [PubMed]

105. Peacey, M.; Wilson, S.; Baird, M.A.; Ward, V.K. Versatile RHDV virus-like particles: Incorporation of antigens by genetic modification and chemical conjugation. Biotechnol. Bioeng. 2007, 98, 968-977. [CrossRef] [PubMed]

106. Billaud, J.-N.; Peterson, D.; Barr, M.; Chen, A.; Sallberg, M.; Garduno, F.; Goldstein, P.; McDowell, W.; Hughes, J.; Jones, J.; et al. Combinatorial Approach to Hepadnavirus-Like Particle Vaccine Design. J. Virol. 2005, 79, 13656-13666. [CrossRef] 
107. Marini, A.; Zhou, Y.; Li, Y.; Taylor, I.J.; Leneghan, D.B.; Jin, J.; Zaric, M.; Mekhaiel, D.; Long, C.A.; Miura, K.; et al. A Universal Plug-and-Display Vaccine Carrier Based on HBsAg VLP to Maximize Effective Antibody Response. Front. Immunol. 2019, 10, 02931. [CrossRef] [PubMed]

108. Zha, L.; Zhao, H.; Mohsen, M.O.; Hong, L.; Zhou, Y.; Li, Z.; Yao, C.; Guo, L.; Chen, H.; Liu, X.; et al. Development of a COVID-19 vaccine based on the receptor binding domain displayed on virus-like particles. bioRxiv 2020. [CrossRef]

109. European Medicines Agency Cervarix: EPAR—Scientific Discussion. Available online: https://www.ema.europa.eu/en/ documents/scientific-discussion/cervarix-epar-scientific-discussion_en.pdf (accessed on 20 December 2020).

110. European Medicines Agency Gardasil 9: EPAR - Product Information-EMA/CHMP/76591/2015. Available online: https://www.ema.europa.eu/en/documents/assessment-report/gardasil-9-epar-public-assessment-report_en.pdf (accessed on 20 December 2020).

111. Qiao, Y.L.; Wu, T.; Li, R.C.; Hu, Y.M.; Wei, L.H.; Li, C.G.; Chen, W.; Huang, S.J.; Zhao, F.H.; Li, M.Q.; et al. Efficacy, Safety, and Immunogenicity of an Escherichia coli-Produced Bivalent Human Papillomavirus Vaccine: An Interim Analysis of a Randomized Clinical Trial. J. Natl. Cancer Inst. 2020, 112, 145-153. [CrossRef]

112. Li, S.W.; Zhang, J.; Li, Y.M.; Ou, S.H.; Huang, G.Y.; He, Z.Q.; Ge, S.X.; Xian, Y.L.; Pang, S.Q.; Ng, M.H.; et al. A bacterially expressed particulate hepatitis E vaccine: Antigenicity, immunogenicity and protectivity on primates. Vaccine 2005, 23, 2893-2901. [CrossRef] [PubMed]

113. Wu, T.; Li, S.W.; Zhang, J.; Ng, M.H.; Xia, N.S.; Zhao, Q. Hepatitis E vaccine development: A 14-year odyssey. Hum. Vaccines Immunother. 2012, 8, 823-827. [CrossRef] [PubMed]

114. Zhu, F.C.; Zhang, J.; Zhang, X.F.; Zhou, C.; Wang, Z.Z.; Huang, S.J.; Wang, H.; Yang, C.L.; Jiang, H.M.; Cai, J.P.; et al. Efficacy and safety of a recombinant hepatitis e vaccine in healthy adults: A large-scale, randomised, double-blind placebo-controlled, phase 3 trial. Lancet 2010, 376, 895-902. [CrossRef]

115. Zheng, M.; Jiang, J.; Zhang, X.; Wang, N.; Wang, K.; Li, Q.; Li, T.; Lin, Q.; Wang, Y.; Yu, H.; et al. Characterization of capsid protein (p495) of hepatitis E virus expressed in Escherichia coli and assembling into particles in vitro. Vaccine 2018, 36, $2104-2111$. [CrossRef]

116. U.S. Food and Drug Administration Summary for Basis of Approval-ENGERIX-B. Available online: https://wayback.archive-it. org/7993/20170404184231/https:/ / www.fda.gov/downloads/BiologicsBloodVaccines/Vaccines/ApprovedProducts/UCM1 10155.pdf (accessed on 20 December 2020).

117. European Medicines Agency Fendrix: EPAR-Scientific Discussion. Available online: https://www.ema.europa.eu/en/ documents/scientific-discussion/fendrix-epar-scientific-discussion_en.pdf (accessed on 20 December 2020).

118. McAleer, W.J.; Buynak, E.B.; Maigetter, R.Z.; Wampler, D.E.; Miller, W.J.; Hilleman, M.R. Human hepatitis B vaccine from recombinant yeast. Nature 1984, 307, 178-180. [CrossRef] [PubMed]

119. Hilleman, M.R. Yeast recombinant hepatitis B vaccine. Infection 1987, 15, 3-7. [CrossRef] [PubMed]

120. Keech, C.; Albert, G.; Cho, I.; Robertson, A.; Reed, P.; Neal, S.; Plested, J.S.; Zhu, M.; Cloney-Clark, S.; Zhou, H.; et al. Phase 1-2 Trial of a SARS-CoV-2 Recombinant Spike Protein Nanoparticle Vaccine. N. Engl. J. Med. 2020, 383, 2320-2332. [CrossRef]

121. Coleman, C.M.; Liu, Y.V.; Mu, H.; Taylor, J.K.; Massare, M.; Flyer, D.C.; Glenn, G.M.; Smith, G.E.; Frieman, M.B. Purified coronavirus spike protein nanoparticles induce coronavirus neutralizing antibodies in mice. Vaccine 2014, 32, 3169-3174. [CrossRef] [PubMed]

122. Smith, G.; Liu, Y.; Flyer, D.; Massare, M.J.; Zhou, B.; Patel, N.; Ellingsworth, L.; Lewis, M.; Cummings, J.F.; Glenn, G. Novel hemagglutinin nanoparticle influenza vaccine with Matrix- $\mathrm{M}^{\mathrm{TM}}$ adjuvant induces hemagglutination inhibition, neutralizing, and protective responses in ferrets against homologous and drifted A(H3N2) subtypes. Vaccine 2017, 35, 5366-5372. [CrossRef]

123. Portnoff, A.D.; Patel, N.; Massare, M.J.; Zhou, H.; Tian, J.-H.; Zhou, B.; Shinde, V.; Glenn, G.M.; Smith, G. Influenza Hemagglutinin Nanoparticle Vaccine Elicits Broadly Neutralizing Antibodies against Structurally Distinct Domains of H3N2 HA. Vaccines 2020, 8, 99. [CrossRef] [PubMed]

124. Glenn, G.M.; Smith, G.; Fries, L.; Raghunandan, R.; Lu, H.; Zhou, B.; Thomas, D.N.; Hickman, S.P.; Kpamegan, E.; Boddapati, S.; et al. Safety and immunogenicity of a Sf9 insect cell-derived respiratory syncytial virus fusion protein nanoparticle vaccine. Vaccine 2013, 31, 524-532. [CrossRef] [PubMed]

125. Fries, L.; Shinde, V.; Stoddard, J.J.; Thomas, D.N.; Kpamegan, E.; Lu, H.; Smith, G.; Hickman, S.P.; Piedra, P.; Glenn, G.M. Immunogenicity and safety of a respiratory syncytial virus fusion protein (RSV F) nanoparticle vaccine in older adults. Immun. Ageing 2017, 14, 8. [CrossRef]

126. del Carmen Morán-García, A.; Rivera-Toledo, E.; Echeverría, O.; Vázquez-Nin, G.; Gómez, B.; Bustos-Jaimes, I. Peptide presentation on primate erythroparvovirus 1 virus-like particles: In vitro assembly, stability and immunological properties. Virus Res. 2016, 224, 12-18. [CrossRef] [PubMed]

127. Ljubojevic, S.; Skerlev, M. HPV-associated diseases. Clin. Dermatol. 2014, 32, 227-234. [CrossRef] [PubMed]

128. Baker, T.S.; Newcomb, W.W.; Olson, N.H.; Cowsert, L.M.; Olson, C.; Brown, J.C. Structures of bovine and human papillomaviruses Analysis by cryoelectron microscopy and three-dimensional image reconstruction. Biophys. J. 1991, 60, 1445-1456. [CrossRef]

129. Neeper, M.P.; Hofmann, K.J.; Jansen, K.U. Expression of the major capsid protein of human papillomavirus type 11 in Saccharomyces cerevisae. Gene 1996, 180, 1-6. [CrossRef]

130. Schädlich, L.; Senger, T.; Kirschning, C.J.; Müller, M.; Gissmann, L. Refining HPV 16 L1 purification from E. coli: Reducing endotoxin contaminations and their impact on immunogenicity. Vaccine 2009, 27, 1511-1522. [CrossRef] 
131. Kamar, N.; Dalton, H.R.; Abravanel, F.; Izopet, J. Hepatitis E virus infection. Clin. Microbiol. Rev. 2014, 27, 116-138. [CrossRef]

132. Hoofnagle, J.H.; Nelson, K.E.; Purcell, R.H. Hepatitis E. N. Engl. J. Med. 2012, 367, 1237-1244. [CrossRef]

133. Tam, A.W.; Smith, M.M.; Guerra, M.E.; Huang, C.-C.; Bradley, D.W.; Fry, K.E.; Reyes, G.R. Hepatitis E virus (HEV): Molecular cloning and sequencing of the full-length viral genome. Virology 1991, 185, 120-131. [CrossRef]

134. Guu, T.S.Y.; Liu, Z.; Ye, Q.; Mata, D.A.; Li, K.; Yin, C.; Zhang, J.; Tao, Y.J. Structure of the hepatitis E virus-like particle suggests mechanisms for virus assembly and receptor binding. Proc. Natl. Acad. Sci. USA 2009, 106, 12992-12997. [CrossRef]

135. Emerson, S.U.; Purcell, R.H. Recombinant vaccines for hepatitis E. Trends Mol. Med. 2001, 7, 462-466. [CrossRef]

136. Yuen, M.-F.; Chen, D.-S.; Dusheiko, G.M.; Janssen, H.L.A.; Lau, D.T.Y.; Locarnini, S.A.; Peters, M.G.; Lai, C.-L. Hepatitis B virus infection. Nat. Rev. Dis. Prim. 2018, 4, 18035. [CrossRef] [PubMed]

137. European Medicines Agency Mosquirix: Public Assessment Report-EMA/CHMP/439337/2015. Available online: https://www. ema.europa.eu/en/documents/medicine-outside-eu/mosquirix-public-assessment-report_en.pdf (accessed on 20 December 2020).

138. Shin, M.D.; Shukla, S.; Chung, Y.H.; Beiss, V.; Chan, S.K.; Ortega-Rivera, O.A.; Wirth, D.M.; Chen, A.; Sack, M.; Pokorski, J.K.; et al. COVID-19 vaccine development and a potential nanomaterial path forward. Nat. Nanotechnol. 2020, 15, 646-655. [CrossRef]

139. Wrapp, D.; Wang, N.; Corbett, K.S.; Goldsmith, J.A.; Hsieh, C.-L.; Abiona, O.; Graham, B.S.; McLellan, J.S. Cryo-EM structure of the 2019-nCoV spike in the prefusion conformation. Science 2020, 367, 1260-1263. [CrossRef] [PubMed]

140. Steinmetz, N.F. Viral nanoparticles as platforms for next-generation therapeutics and imaging devices. Nanomed. Nanotechnol. Biol. Med. 2010, 6, 634-641. [CrossRef] [PubMed]

141. Bajaj, S.; Banerjee, M. Engineering Virus Capsids Into Biomedical Delivery Vehicles: Structural Engineering Problems in Nanoscale. J. Biomed. Nanotechnol. 2015, 11, 53-69. [CrossRef]

142. Schwarz, B.; Uchida, M.; Douglas, T. Biomedical and Catalytic Opportunities of Virus-Like Particles in Nanotechnology. Adv. Virus Res. 2017, 97, 1-60. [CrossRef]

143. Galaway, F.A.; Stockley, P.G. MS2 Viruslike Particles: A Robust, Semisynthetic Targeted Drug Delivery Platform. Mol. Pharm. 2013, 10, 59-68. [CrossRef]

144. Waghwani, H.K.; Uchida, M.; Fu, C.Y.; Lafrance, B.; Sharma, J.; McCoy, K.; Douglas, T. Virus-Like Particles (VLPs) as a Platform for Hierarchical Compartmentalization. Biomacromolecules 2020, 21, 2060-2072. [CrossRef]

145. Sharma, J.; Uchida, M.; Miettinen, H.M.; Douglas, T. Modular interior loading and exterior decoration of a virus-like particle. Nanoscale 2017, 9, 10420-10430. [CrossRef]

146. Kimchi-Sarfaty, C.; Ben-Nun-Shaul, O.; Rund, D.; Oppenheim, A.; Gottesman, M.M. In Vitro -Packaged SV40 Pseudovirions as Highly Efficient Vectors for Gene Transfer. Hum. Gene Ther. 2002, 13, 299-310. [CrossRef] [PubMed]

147. Kimchi-Sarfaty, C.; Vieira, W.D.; Dodds, D.; Sherman, A.; Kreitman, R.J.; Shinar, S.; Gottesman, M.M. SV40 Pseudovirion gene delivery of a toxin to treat human adenocarcinomas in mice. Cancer Gene Ther. 2006, 13, 648-657. [CrossRef]

148. Chou, M.-I.; Hsieh, Y.-F.; Wang, M.; Chang, J.; Chang, D.; Zouali, M.; Tsay, G.J. In vitro and in vivo targeted delivery of IL-10 interfering RNA by JC virus-like particles. J. Biomed. Sci. 2010, 17, 51. [CrossRef]

149. Lu, X.; Thompson, J.R.; Perry, K.L. Encapsidation of DNA, a protein and a fluorophore into virus-like particles by the capsid protein of cucumber mosaic virus. J. Gen. Virol. 2012, 93, 1120-1126. [CrossRef]

150. Barwal, I.; Kumar, R.; Kateriya, S.; Dinda, A.K.; Yadav, S.C. Targeted delivery system for cancer cells consist of multiple ligands conjugated genetically modified CCMV capsid on doxorubicin GNPs complex. Sci. Rep. 2016, 6, 37096. [CrossRef]

151. Enomoto, T.; Kawano, M.; Fukuda, H.; Sawada, W.; Inoue, T.; Haw, K.C.; Kita, Y.; Sakamoto, S.; Yamaguchi, Y.; Imai, T.; et al. Viral protein-coating of magnetic nanoparticles using simian virus 40 VP1. J. Biotechnol. 2013, 167, 8-15. [CrossRef] [PubMed]

152. Li, F.; Zhang, Z.-P.; Peng, J.; Cui, Z.-Q.; Pang, D.-W.; Li, K.; Wei, H.-P.; Zhou, Y.-F.; Wen, J.-K.; Zhang, X.-E. Imaging Viral Behavior in Mammalian Cells with Self-Assembled Capsid-Quantum-Dot Hybrid Particles. Small 2009, 5, 718-726. [CrossRef] [PubMed]

153. Chen, C.; Daniel, M.-C.; Quinkert, Z.T.; De, M.; Stein, B.; Bowman, V.D.; Chipman, P.R.; Rotello, V.M.; Kao, C.C.; Dragnea, B. Nanoparticle-Templated Assembly of Viral Protein Cages. Nano Lett. 2006, 6, 611-615. [CrossRef] [PubMed]

154. Goicochea, N.L.; De, M.; Rotello, V.M.; Mukhopadhyay, S.; Dragnea, B. Core-like Particles of an Enveloped Animal Virus Can Self-Assemble Efficiently on Artificial Templates. Nano Lett. 2007, 7, 2281-2290. [CrossRef]

155. Johnson, J.E.; Speir, J.A. Quasi-equivalent viruses: A paradigm for protein assemblies. J. Mol. Biol. 1997, 269, 665-675. [CrossRef]

156. Biddlecome, A.; Habte, H.H.; McGrath, K.M.; Sambanthamoorthy, S.; Wurm, M.; Sykora, M.M.; Knobler, C.M.; Lorenz, I.C.; Lasaro, M.; Elbers, K.; et al. Delivery of self-amplifying RNA vaccines in in vitro reconstituted virus-like particles. PLoS ONE 2019, 14, e0215031. [CrossRef] 